\title{
Sustainable ferrate oxidation: Reaction chemistry, mechanisms and removal of pollutants in wastewater
}

\author{
Afzal Ahmed Dar ${ }^{\mathrm{a}}$, Bao Pan ${ }^{\mathrm{b}}$, Jiani Qin ${ }^{\mathrm{a}}$, Qiuhui Zhu ${ }^{\mathrm{a}}$, Eric Lichtfouse ${ }^{\mathrm{c}}$, Muhammad Usman ${ }^{\mathrm{d}}$, \\ Chuanyi Wang ${ }^{\text {a, * }}$ \\ ${ }^{a}$ School of Environmental Science and Engineering, Shaanxi University of Science and Technology, Xi'an, PR China \\ ${ }^{\mathrm{b}}$ School of Chemistry and Chemical Engineering, Shaanxi University of Science and Technology, Xi'an, PR China \\ ${ }^{\mathrm{c}}$ Aix-Marseille University, CNRS, IRD, INRA, Coll France, CEREGE, Aix-en-Provence, 13100, France \\ ${ }^{\mathrm{d}}$ PEIE Research Chair for the Development of Industrial Estates and Free Zones, Center for Environmental Studies and Research, Sultan Qaboos University, Al-Khoud \\ 123, Muscat, Oman
}

\section{A R T I C L E I N F O}

\section{Keywords:}

Ferrate

Micropollutant

Pharmaceutical pollutants

Wastewater

Reaction kinetics \& mechanisms

\begin{abstract}
A B S T R A C T
This review is intended to evaluate the use of ferrate (Fe(VI)), being a green coagulant, sustainable and reactive oxidant, to remove micro pollutants especially pharmaceutical pollutants in contaminated water. After a brief description of advanced oxidation processes, fundamental dimensions regarding the nature, reactivity, and chemistry of this oxidant are summarized. The degradation of contaminants by Fe(VI) involves several mechanisms and reactive agents which are critically evaluated. The efficiency and chemistry of Fe(VI) oxidation differs according to the reaction conditions and activation agent, such as soluble Fe(VI) processes, which involve Fe(VI), UV light, and electro-Fe(VI) oxidation. Fe(VI) application methods (including single dose, multiple doses, chitosan coating etc), and $\mathrm{Fe}(\mathrm{VI})$ with activating agents (including sulfite, thiosulfate, and UV) are also described to degrade the micro pollutants. Besides, application of $\mathrm{Fe}(\mathrm{VI})$ to remove pharmaceuticals in wastewater are intensely studied. Electrochemical prepared $\mathrm{Fe}(\mathrm{VI})$ has more wide application than wet oxidation method. Meanwhile, we elaborated $\mathrm{Fe}(\mathrm{VI})$ performance, limitations, and proposed innovative aspects to improve its stability, such as the generation of Fe(III), synergetic effects, nanopores entrapment, and nanopores capsules. This study provides conclusive direction for synergetic oxidative technique to degrade the micro pollutants.
\end{abstract}

\section{Introduction}

Urban growth and industrial development have induced a sharp increase in commercial products to fulfil current market demands and, in turn, worldwide pollution (Bhavya et al., 2021; Chen et al., 2018; Satapute et al., 2019) Surface waters contain various micro pollutants including emerging organic contaminants, such as toxic hormonal chemicals, beauty products, and toxins (Gago-Ferrero et al., 2017; Klatte et al., 2017). These micro pollutants have detrimental effects on human health, marine ecosystem, and biodiversity (Jepson and Law, 2016; Yang et al., 2017; Ye et al., 2017). The continued release to the ecosystem of toxins, pharmaceuticals, flame retardants, and pesticides could have undesirable harmful effects on aquatic ecosystems (Kalliora et al., 2018). The long-term use of polluted water comprised with organic pollutant and heavy metals could present a severe danger to human health (Geetha et al., 2021; Shin et al., 2018).
Developing new techniques to remove organic contaminants, mainly pharmaceuticals, especially durable organic compounds, is highly demanding for water treatment (Paidi et al., 2021; Premnath et al., 2021). Different traditional methods, including filtration, adsorption, oxidation, and photocatalytic processes, are limited by comparatively high running costs and unsatisfactory performances. The focus of the current research is to develop renewable technologies that rely on eco-sustainable agents and are highly efficient (Huo et al., 2020; Sharma et al., 2013).

Advanced oxidation processes (AOPs) are distinguished by developing a potent oxidant called strong radical at sufficiently high concentrations to treat water. The target contaminant can be mineralized into $\mathrm{CO}_{2}$, and $\mathrm{H}_{2} \mathrm{O}$, which are the most stable conclusive end products of chemical oxidation under appropriate operating conditions, such as ample contact time and concentration. The exceptional concept of AOPs for chemical reactions is that they are thoroughly defined as

\footnotetext{
* Corresponding author.

E-mail address: wangchuanyi@sust.edu.cn (C. Wang).
} 
"environmentally friendly" for this purpose (Azbar et al., 2005). It is possible to describe the primary treatment of AOPs in two steps: one is the generation of hydroxyl radicals $(\mathrm{OH} \bullet)$, and the other is the oxidative reaction of pollutants with the generated radicals. The generation of $(\mathrm{OH}$

-) might be by using $\mathrm{TiO}_{2} / \mathrm{H}_{2} \mathrm{O}_{2}, \mathrm{UV}, \mathrm{UV} / \mathrm{O}_{3}, \mathrm{UV} / \mathrm{H}_{2} \mathrm{O}_{2}$, and one or two step processes (Pan et al., 2020b; Yonar, 2011).

Advanced oxidation techniques can easily and generally remove hormones, pharmaceuticals, and dyes (Mackul'ak et al., 2013; Yang et al., 2017). An advanced oxidation process comprised with different and unique advanced oxidation techniques for wastewater treatment. For example, the Fenton reaction and ozonation have been commonly useful to remove the toxic organic compounds (Chen et al., 2016; Liu et al., 2016; Liu et al., 2018; Usman and Ho, 2020; Wang and Xu, 2012). Besides, ozone produces additional toxic intermediate as compare to their parent compound (Dar et al., 2019). Permanganate and peroxydisulfate have contributed significantly to chemical reactions, but both oxidation mechanisms rely on $\mathrm{pH}$ (Hu and Xia, 2018). Peroxydisulfate, which requires in situ experiment analysis, is reasonably stable at ambient temperatures of $\sim 20^{\circ} \mathrm{C}$ (Luo et al., 2017; Luo et al., 2018; Xiao et al., 2017; Xiao et al., 2015). A significant risk of secondary exposure is posed by sulphate and its by-products. Oxidation of permanganate creates manganese oxides, which contributes to pore persevering and decreases the effectiveness of remediation ( $\mathrm{Li}$ and Schwartz, 2005; Pan et al., 2019). The peroxone mechanism (coupling ozone with $\mathrm{H}_{2} \mathrm{O}_{2}$ ) is unreliable, leading to handling and storage issues (Fuerhacker et al., 2001; Zhu et al., 2015).

Use of advanced oxidation processes have received significant attention among the scientific community to remove organic micro pollutants. However, traditional advanced oxidation techniques (like Fenton oxidation, persulfate reagent) face certain limitations such as $\mathrm{pH}$ and temperature dependence, toxic intermediates, prolonged reaction time, high cost, handling, and storage issues. At the same time, $\mathrm{Fe}(\mathrm{VI})$ oxidation has been recognized as a green technology with non-toxic intermediates and quick treatment. There are several Fe(VI) application methods in reaction system (including single dose, multiple dose and encapsulation), which need to be addressed for more progressive implication. Even, Fe(VI) implication to degrade pollutant is inevitably complex. Our notion is to elucidate the fundamentals, reaction chemistry, reaction mechanism and to highlight emerging trends in $\mathrm{Fe}(\mathrm{VI})$ degradation.

Recently author reported the review article related to sewage sludge treatment (SST) with $\mathrm{Fe}(\mathrm{VI})$, they highlighted the $\mathrm{Fe}(\mathrm{VI})$ contributions related to SST including (sludge minimization, dewatering, anaerobic fermentation and removal of pollutant. The authors conclude with these remarks that stability concern should be overcome and the in-situ preparation can reduce the manufacturing cost (Hu et al., 2020).

Topics covered in this review are the basic dimensions of $\mathrm{Fe}(\mathrm{VI})$, reaction mechanism, $\mathrm{Fe}(\mathrm{VI})$ implications, and $\mathrm{Fe}(\mathrm{VI})$ involvement to remediate various drugs. We briefly described the Fe(VI) efficacy by using different implication methods, such as single dose, multiple-dose, and encapsulation. Also, we highlighted the advancement in $\mathrm{Fe}(\mathrm{VI})$ oxidation and engraved various activation agents coupled with $\mathrm{Fe}(\mathrm{VI})$. Basic queries include: how to stabilize Fe(VI) for complete degradation? How to coupled Fe(III) radical, which are more reactive than $\mathrm{Fe}(\mathrm{VI})$ ? Which activation agent is more reactive and productive? How photo generated electron contributes synergetic effect to $\mathrm{Fe}(\mathrm{VI})$ ?

\section{Advanced oxidation processes}

The explanation of advanced oxidation techniques comprising their specific characteristics, generated radical, redox potential and their limitation has been provided in Table 1. According to these finding, Fenton having more redox potential as compared to other techniques with $\mathrm{pH}$-based limitations. Besides, $\mathrm{KMnO}_{4}$ having the least redox potential with the limitation of acid content enhancement.

$\mathrm{Fe}(\mathrm{VI})$ is, therefore, an efficient and attractive agent for treating different organic compounds in water (Sharma et al., 2011). Fe(VI) is the principal ingredient to degrade the organic pollutant. This is a thoughtful approach since there is a significant consistency of compounds (high valent iron) in aqueous solution. It is a well-known fact, from the other side, that $\mathrm{Fe}(\mathrm{V})$ is more sensitive as compare to $\mathrm{Fe}(\mathrm{VI})$ (Sharma et al., 2013).

\subsection{Basic dimensions of $\mathrm{Fe}(\mathrm{VI})$}

$\mathrm{Fe}(\mathrm{VI})$ is the inorganic anion with the chemical formula $\left[\mathrm{FeO}_{4}\right]^{2-}$. It is sensitive to light, gives light violet colour to a solution, and is one of the most effective water-stable oxygen species (Yang et al., 2017). Fe(VI) can be castoff as an environmental treatment for drinking water and wastewater (Evgenidou et al., 2015). Fe(VI) electrochemical procedure can be called a "natural" and simple solution since it usually requires a one-step reaction to convert of $\mathrm{Fe}(0)$ into $\mathrm{Fe}(\mathrm{VI})$ for the oxidation,

Table 1

Elucidation of advanced oxidation techniques with their specific characteristics, including generated radical, redox potential, and limitations.

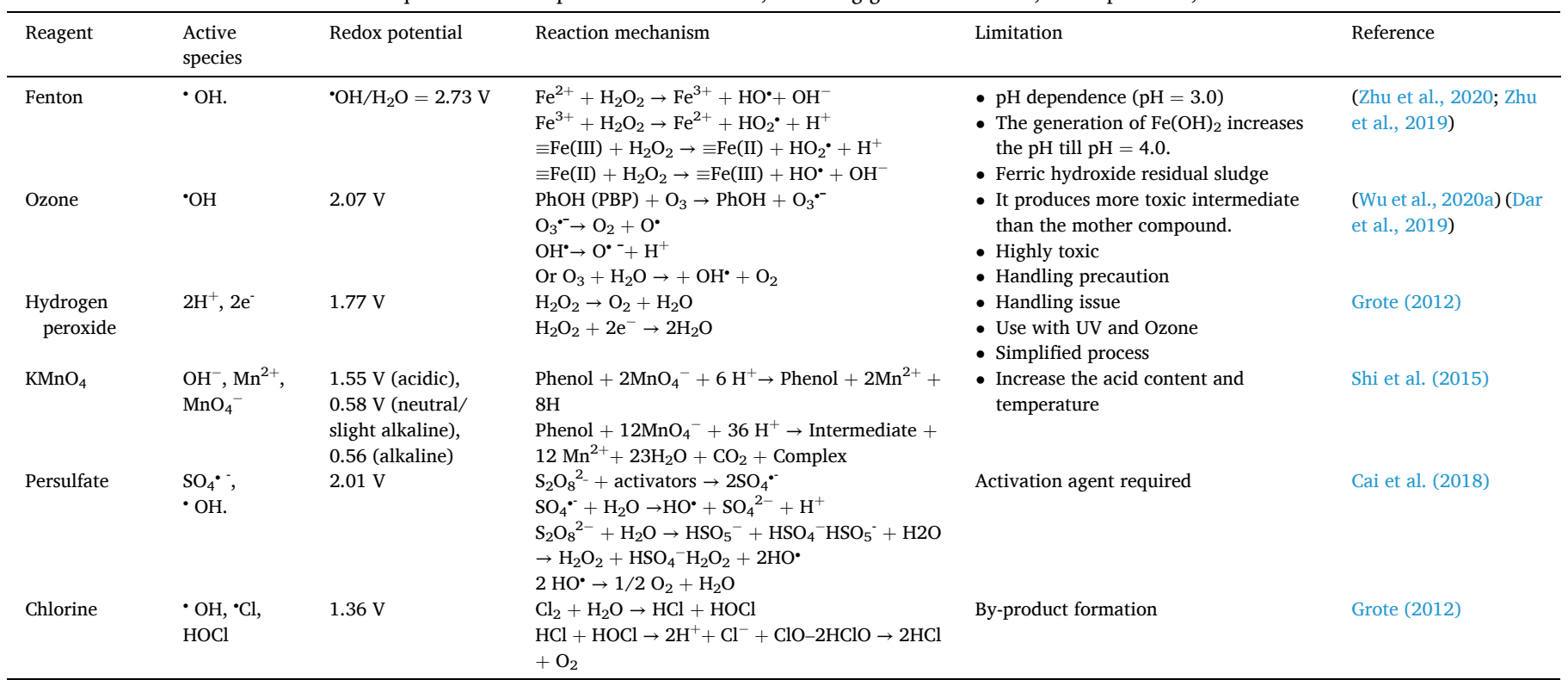


without dangerous or costly chemicals (Evgenidou et al., 2015).

Molecular $\mathrm{Fe}(\mathrm{VI})$ and its water treatment mechanisms: $\mathrm{Fe}(\mathrm{VI})$ is usually a dark red powder crystal with a slight metallic luster, which is very soluble in water from a deep purple to violet colour solution. Fe(VI) can be used at the same time as an oxidant, disinfectant, adsorbent, flocculant, coagulant aid, and bactericide, flocculation, sterilization, adsorption as one of the multi-functional high-efficiency water treatment oxidants (Jiang and Lloyd, 2002). Fe(VI) has many applications in water treatment as a highly efficient multifunctional water treatment agent. (Jiang et al., 2016).

At acidic or neutral $\mathrm{pH}$ values, the $\mathrm{Fe}(\mathrm{VI})$ anion is fragile, decomposing to iron (Fe(IV). The decrease passes through degradation products, in which iron has $\mathrm{Fe}(\mathrm{V})$ and $\mathrm{Fe}(\mathrm{IV})$ oxidation states, which are extra responsive as compare to $\mathrm{Fe}(\mathrm{VI})$ (Sharma, 2013). In alkaline conditions, $\mathrm{Fe}(\mathrm{VI})$ is soluble, and stays reactive at a $\mathrm{pH} 8.0$ or 9.0 for around $8-9 \mathrm{~h}$ (Sharma, 2012). Fe(VI) under an acidic environment has a typical reducing potential of $2.20 \mathrm{~V}$ and is substantially more than that of ozone $(2.08 \mathrm{~V})$ (Sharma, 2012). Fe(VI) is susceptible to reactions of degradation, which leave no substitute in treated water. Fe(VI) has been used for multipurpose purification (Jiang, 2014) like a wide variety of microorganisms (e.g. pathogen MS2 and Escherichia coli) (Prucek et al., 2013), micropollutants (e.g., endocrine disruptors and antimicrobials) (Casbeer et al., 2013), poisonous metals (e.g. cadmium and arsenic) and phosphates (Jiang, 2014; Sharma et al., 2013). Fe(VI) is also able to provide a high degree of fecal coliform inhibition at very low doses through a reasonable disinfection rate of $>99.9 \%$ (Jiang and Lloyd, 2002; Jiang et al., 2006). Fe(VI) are wonderful antibiotic salts that can remove viruses (Lee et al., 2014). Fe(VI) has also established promising potential for treating N-nitrosodimethylamine (NDMA) catalysts, thus reducing the risk for NDMA formation (Lee et al., 2008). One of Fe(VI) 's vital benefits is that if the water sample produces bromide ions, it can reduce possible carcinogenic bromate ions (Sharma et al., 2011).

Although chemicals like chlorine $\left(\mathrm{Cl}_{2}\right)$ may kill certain microorganisms such as anthrax, it can also contain disinfectant waste materials (DBPs), which may pose a danger to human health (Sharma, 2004). Therefore, over chlorine, various antiseptics (e.g., ozone) were given preference. However, it is understood that these substitutes shape multiple other waste material products, which also harmed individuals and aquatic animals to some point (Jiang et al., 2007). Over the previous two decades, considerable effort has been made to develop Fe(VI) approaches to degrade microorganisms, dyes, inorganic contaminants, and aquatic entertainment to address these problems (Jiang et al., 2013; Sharma, 2004). Water clean-up is susceptible to coagulation and oxidation/decontamination (Jiang et al., 2006). The Fe(VI) ion has become an excellent disinfectant because of its oxidising force (Gilbert et al., 1976). The abridged Escherichia coli (E. coli) levels were studied after addition of $\mathrm{Fe}(\mathrm{VI})$. It has a high oxidising ability relative to traditional disinfectants at $4.2-6.0 \mathrm{mgL}^{-1}$ concentrations, with a disinfectant potential as strong as mono-chloro amine. There was a $99 \%$ reduction in coliforms among the effects of this analysis. $\mathrm{Fe}(\mathrm{VI})$ is a composition, which can act for heavy metals and suspended materials as an oxidant, biocide, and flocculant. In addition to molecular oxygen, no harmful residues are left in the treated water (Licht et al., 2008).

In contrast to other advanced oxidation techniques, $\mathrm{Fe}(\mathrm{VI})$ crops a small amount of sludge, which removes other toxins and makes additional sludge treatment convenient for use (Diak and Örmeci, 2016; Zhang et al., 2016). Fe(VI) oddly exhibit coagulating features as toxins are oxidised simultaneously. For coagulation, $\mathrm{pH}$ : 7.0 could be optimal as the oxidation rate decreases more as the $\mathrm{pH}$ value increases, as shown in a study (Sharma, 2004). Some researchers tried to boost the behaviour of Fe(VI) at a limited/acidic pH (Manoli et al., 2017a; Manoli et al., 2017b). Fe(VI) was mixed with ferric chloride in a new analysis to handle 12 different natural water forms (Jiang et al., 2016). This Fe(VI), employing the coagulation process, it was a rational system in which organic matter was removed from the water sources, which showed that $\mathrm{Fe}(\mathrm{VI})$ operated as the coagulant for wastewater and water treatment.
There are some other favourable properties for Fe(VI), including the production of a few waste products, a lack of microbial or toxin byproducts, the capacity to generate stable salts, and a high oxidising strength across the entire $\mathrm{pH}$ spectrum. In various climate applications, these properties make it a "greener" tool. Mutagenic and carcinogenic compounds can occur with traditional and less eco-sustainable chemicals along with significant human health consequences. As discussed, the amputation of antibiotics or drugs using $\mathrm{Fe}(\mathrm{VI})$ is still in remediation's highlight, and additional research in this field is required. The usage of $\mathrm{Fe}(\mathrm{VI})$ as a solid oxidant for the elimination of biocontaminants is also essential for the following purposes (Jiang et al., 2006; Norcross et al., 1997), coagulant for disabling infectious microorganisms (Jiang et al., 2003; Jiang et al., 2006), and as a way of removing inorganic contaminants, colloidal and metals particles in particular (Jiang et al., 2003).

\subsection{Ferrate application methods}

There are numbers of methods to add/use $\mathrm{Fe}(\mathrm{VI})$ in the reaction system, such as single dose (once in a reaction system), multiple-dose (step by step addition), and encapsulation (coating by different agents) method. Single dose application leads to quick degradation, but it may skip the necessary information about reaction mechanism and intermediate. Besides, multiple doses help to generate more and conclusive information about reaction mechanism and intermediates. While slow and conclusive release of $\mathrm{Fe}(\mathrm{VI})$ can also be achieved by encapsulation. By following these concerns, Table 2 provides the details, including their method, targeted compound, degradation rate, and limitations.

\subsection{Reaction mechanism of $\mathrm{Fe}(\mathrm{VI})$}

$\mathrm{Fe}(\mathrm{VI})$ is an environment friendly, water-processing oxidant and chemical capable of performing a twofold oxidation and disinfection role. Although, $\mathrm{Fe}(\mathrm{VI})$ is relatively stable, $\mathrm{Fe}(\mathrm{IV})$ \& $\mathrm{Fe}(\mathrm{V})$ species decline in seconds, depending on the reaction system (physical and chemical conditions) (Lee et al., 2014). Fe(VI) interacts with organic contaminants by $\pi-\pi$ interaction, while $\mathrm{Fe}$ (IV) or $\mathrm{Fe}(\mathrm{V})$ were the main oxidative agents during the reaction, as they have more redox potential than $\mathrm{Fe}$ (VI). It is a well-known fact, from the other side, that $\mathrm{Fe}(\mathrm{V})$ is more sensitive as compare to Fe(VI) (Sharma et al., 2013).

Different pathways may explain the reactivity of $\mathrm{Fe}(\mathrm{VI})$ for the deprivation of contaminants (X). The first option is the reduction of Fe (VI) to $\mathrm{Fe}(\mathrm{V})$ by radical-forming electron transfer mechanism (Eq. 1). Another direction is that the transition of two electrons produces radicals (Eq. 2) or dimers (Eq. 3). The radical species formed during reaction may further react with $\mathrm{Fe}(\mathrm{VI})$ (Eq. 4). Lastly, it is possible to detect oxygen atom transfer (Eq. 5) (Sharma, 2002). For example, this process has been reported for $\mathrm{Fe}(\mathrm{IV})$ and phenylhydroxylamine-forming aniline (Lee et al., 2005). Reactions concerning the pollutant (X) mentioned in Eqs. 1-5. In addition, Fe(VI) self-decomposition can occur, proceeding to the generation of species of $\mathrm{Fe}(\mathrm{V}), \mathrm{Fe}(\mathrm{IV})$, and reactive oxygen including $\mathrm{O}_{2}{ }^{-}, \mathrm{H}_{2} \mathrm{O}_{2}$ as well. Reactive oxygen species may be intricated in the pollutant degradation.

$\mathrm{Fe}(\mathrm{VI})+\mathrm{X} \rightarrow \mathrm{Fe}(\mathrm{V})+\mathrm{X}$

$\mathrm{Fe}(\mathrm{VI})+\mathrm{X} \rightarrow \mathrm{Fe}(\mathrm{IV})+2 \mathrm{X}$

or

$\mathrm{Fe}(\mathrm{VI})+\mathrm{X} \rightarrow \mathrm{Fe}(\mathrm{IV})+\mathrm{X}_{2}$ Eq.3

$\mathrm{Fe}(\mathrm{VI})+\mathrm{X} \rightarrow \mathrm{Fe}(\mathrm{IV}) / \mathrm{Fe}(\mathrm{V})+$ product $\mathrm{X}$ Eq.4

$\mathrm{Fe}(\mathrm{VI})+\mathrm{X} \rightarrow \mathrm{Fe}(\mathrm{IV})+\mathrm{XO}$

$\mathrm{Fe}(\mathrm{VI})$ responds hastily with organic medieties (electron rich) 
Table 2

The methodology of ferrate application with their reaction conditions, including the type of pollutant, degradation rate/time, and limitations.

\begin{tabular}{|c|c|c|c|c|c|c|c|c|}
\hline Method & Pollutant & $\mathrm{pH}$ & Degradation rate & \multicolumn{2}{|c|}{$\begin{array}{l}\text { Molar ratio (Fe } \\
\text { (VI)/Pollutant) }\end{array}$} & $\begin{array}{l}\text { Degradation } \\
\text { time }\end{array}$ & Limitation/remarks & Reference \\
\hline Single Dose & Bisphenol F & $6.0-10.0$ & $\begin{array}{l}2.0 \times 10^{3} \mathrm{M}^{-1} \mathrm{~s}^{-1} \\
\text { to } 1.2 \times 10^{2} \mathrm{M}^{-1} \\
\mathrm{~s}^{-1}\end{array}$ & $10: 1$ & & $5 \mathrm{~min}$ & $\begin{array}{l}\text { - Quick degradation can be observed in } \\
\text { few early seconds ( } 30 \mathrm{~s}) \text {; this may skip } \\
\text { the necessary information regarding } \\
\text { reaction intermediate. } \\
\text { - More the Fe(VI) dose more the } \\
\text { degradation, more residual as well. }\end{array}$ & $\begin{array}{l}\text { Yang et al. } \\
(2020)\end{array}$ \\
\hline \multirow[t]{3}{*}{ Multiple Dose } & \multirow[t]{3}{*}{$\begin{array}{l}\text { Fluoroquinolone } \\
\text { antibiotics }\end{array}$} & \multirow[t]{3}{*}{7.0} & & $\begin{array}{l}\text { single } \\
\text { addition }\end{array}$ & & $\begin{array}{l}10 \min (85 \% \\
\text { removal) }\end{array}$ & \multirow[t]{4}{*}{$\begin{array}{l}\text { - Complicated reaction setup. } \\
\text { - Time-consuming }\end{array}$} & \multirow[t]{4}{*}{$\begin{array}{l}\text { Feng et al. } \\
(2016)\end{array}$} \\
\hline & & & & $\begin{array}{l}\text { multiple } \\
\text { addition }\end{array}$ & $5: 1$ & $\begin{array}{l}80 \text { min } \\
\text { (complete } \\
\text { removal) }\end{array}$ & & \\
\hline & & & & Fe(VI): FLU & & & & \\
\hline \multicolumn{7}{|l|}{$\begin{array}{l}\text { Encapsulation/ } \\
\text { material }\end{array}$} & & \\
\hline Chitosan & Methyl orange & 6.5 & & $5 \mathrm{mg} \mathrm{L}^{-1}$ & & $80 \%$ & $\begin{array}{l}\text { - Acidic medium required to engulf the } \\
\text { capsulated pallet/Fe(VI). } \\
\text { - High concentration of chitosan required } \\
\text { to maximize the efficiency ( } 2 \% \\
\text { chitosan). } \\
\text { - Buffering agent required } \\
\text { (petrochemical) which may enhance } \\
\text { pollution. } \\
\text { - Characterization tools required for } \\
\text { assessment. } \\
\text { - Time consuming }\end{array}$ & $\begin{array}{l}\text { Chen et al. } \\
\text { (2019) }\end{array}$ \\
\hline $\begin{array}{l}\text { Ethyl cellulose } \\
\text { and paraffin }\end{array}$ & $\begin{array}{l}\text { 2-sec-butyly-4,6 } \\
\text { dinitrophenol }\end{array}$ & 6.5 & & $93 \%$ & & $80 \mathrm{~min}$ & $\begin{array}{l}\text { - Paraffins are saturated hydrocarbon, } \\
\text { and categorically not in green material. } \\
\text { - Characterization tool required. } \\
\text { - Degradation influencing by coating to } \\
\text { ferrate ratio. } \\
\text { - Time consuming and complex } \\
\text { methodology. }\end{array}$ & $\begin{array}{l}\text { Wang et al. } \\
\text { (2009) }\end{array}$ \\
\hline
\end{tabular}

including amines, anilines, phenols, olefins, etc (Shi et al., 2015). Besides, adsorption may occur on $\mathrm{Fe}(\mathrm{VI})$ 's precipitating reaction items. Besides, not only basic hydrocarbons, chlorinated ethylene, phenol, and also multifaceted organic contaminants with a more complex composition were examined for the reactivity of Fe(VI) (Yang et al., 2020).

The main reaction between organic pollutants and $\mathrm{Fe}(\mathrm{VI})$ is electron transfer between pollutants and Fe(VI). As Fig. 1 revealing, the reaction mechanism of $\mathrm{Fe}(\mathrm{VI})$ with organic pollutants mainly includes 1-e-or 2-e transfer mechanism/processes. 1-e-transfer of Fe (VI) to Fe (V), 2-e-Fe (IV) was formed by the transformation. The intermediate valence $\mathrm{Fe}$ (V) \& Fe (IV) can also continue to undergo 1-e- \& 2-e-transfer to generate a lower valence. However, dissolved oxygen often exists in water, so the end product of $\mathrm{Fe}(\mathrm{VI})$ reaction is $\mathrm{Fe}(\mathrm{OH})_{3}$. The mechanism of $\mathrm{Fe}(\mathrm{VI})$ oxidation is explained from three aspects: (1) the second-order reaction rate constant: fitting the kinetic experimental results; (2) stoichiometric method: reasoning according to the stoichiometric ratio of $\mathrm{Fe}$ (VI) to $\mathrm{X}$ and the number of electron gains and losses; (3) the reaction products were identified by modern precise analytical instruments (Sharma et al., 2015).

$\mathrm{Fe}(\mathrm{VI})$ degradation of organic compounds mainly involve nitrogencontaining and sulfur-containing compounds, amines, phenols, and alcohols. The second order reaction rate constants of several substituted phenols, 17 $\beta$-estradiol, $17 \alpha$-ethinylestradiol, and bisphenol-A were determined with the change of $\mathrm{pH}(6.0-11.0)$. The results showed that the $k$ of three endocrine disruptors fluctuated from $6.4 \times 10^{2}$ to $7.7 \times$ $10^{2} \mathrm{M}^{-1} \mathrm{~s}^{-1}$ with pH 7.0. (Lee et al., 2004), (Sharma et al., 2015). Some phenolic substances are between 6.6 and $3.6 \times 10^{3} \mathrm{M}^{-1} \mathrm{~s}^{-1}$, which fully shows the capacity of $\mathrm{Fe}(\mathrm{VI})$ oxidation of phenolic endocrine disruptors. Yang et al. (2014) studied the reaction kinetics, mechanism and toxicity evaluation, and assessed the potential of $\mathrm{Fe}$ (VI) to degrade tetrabromobisphenol A (TBA). The results show that the second order reaction rate constant among $\mathrm{Fe}(\mathrm{VI})$ and tetrabromobisphenol $\mathrm{A}$ is 7.9 $( \pm 0.3) \times 10^{3}$ to $3.3 \times 10^{1} \mathrm{M}^{-1} \mathrm{~s}^{-1}$, with half-life of $1.7 \mathrm{~s}-419.3 \mathrm{~s}$ in the range of $\mathrm{pH}$ 7.0-10.0. Compared with $\mathrm{BPA}, \mathrm{Fe}(\mathrm{VI})$ is easier to oxidize TBBPA. Fe(VI) can abolish, and convert TBBPA molecules by $\beta$-fracture reaction, and produce low brominated products (Yang et al., 2014).

According to the product analysis (Fig. 2), Fe(VI) oxidizes the phenol part of tetrabromobisphenol-A through an electron transfer mechanism. In the first step, a phenoxy radical and $\mathrm{Fe}(\mathrm{V})$ is generated. The phenoxy is immobilized by the electron resonance effect and forms the free radical $\mathrm{R} 1$, and then the self-made radical $\mathrm{R}-1$ forms a new free radical $\mathrm{R}-2, \mathrm{R}-2$ through $\beta$-cleavage (cleavage between the benzene ring and the isopropyl). Free radicals react with $\mathrm{H}_{2} \mathrm{O}$ and $\mathrm{CH}_{3} \mathrm{OH}$ to generate corresponding products A \& B (Yang et al., 2014).

Zhou and Jiang (2015a) studied the kinetics of diclofenac (DCF), sulfamethoxazole (SMX), bezafibrate and carbamazepine oxidation by $\mathrm{Fe}(\mathrm{VI})$ with varying $\mathrm{pH}$ from 6.0 to 9.0 and $\mathrm{Fe}(\mathrm{VI})$ dose from 1 to $5 \mathrm{mg}$ $\mathrm{L}^{-1}$. The results revealed that bezafibrate (BZF) degeneration was less than $25 \%$, with the second order reaction kinetics. The outcome of $\mathrm{pH}$ on the degradation efficiency of four substances was different. The second order reaction rate constants at $\mathrm{pH} 8.0$ and 9.0 are $360 \pm 17$ and $1.26 \pm 0.02 \mathrm{M}^{-1} \mathrm{~s}^{-1}$, respectively. Meanwhile, the second order reaction rate constant with bezafibrate is less than $0.5 \mathrm{M}^{-1} \mathrm{~s}^{-1}$ at $\mathrm{pH}=8.0 \& 9.0$ (Zhou and Jiang, 2015b).

Besides, the oxidation intermediates of sulfamethoxazole and diclofenac were recognized, and the possible conversion path was speculated, but the products of bezafibrate were not noticed. In the reaction process, $\mathrm{Fe}(\mathrm{VI})$ attacks the amino nitrogen of sulfamethoxazole, leading to the hydrogen extraction reaction and oxygen insertion reaction, and the hydroxylation reaction. At the same time, through oxygen transfer, the attack amino acid part leads to the formation of nitrobenzene derivatives (Fig. 3). When $\mathrm{Fe}(\mathrm{VI})$ attacks the amino part of diclofenac, it lead to mono aromatic ring products, decarboxylation can also occur, leading to the formation of amino quinone derivatives. Besides, hydroxyl substitution reactions occur in aromatic ring and side-chain to generate dihydroxylated products (Fig. 4) (Zhou and Jiang, 2015a). 


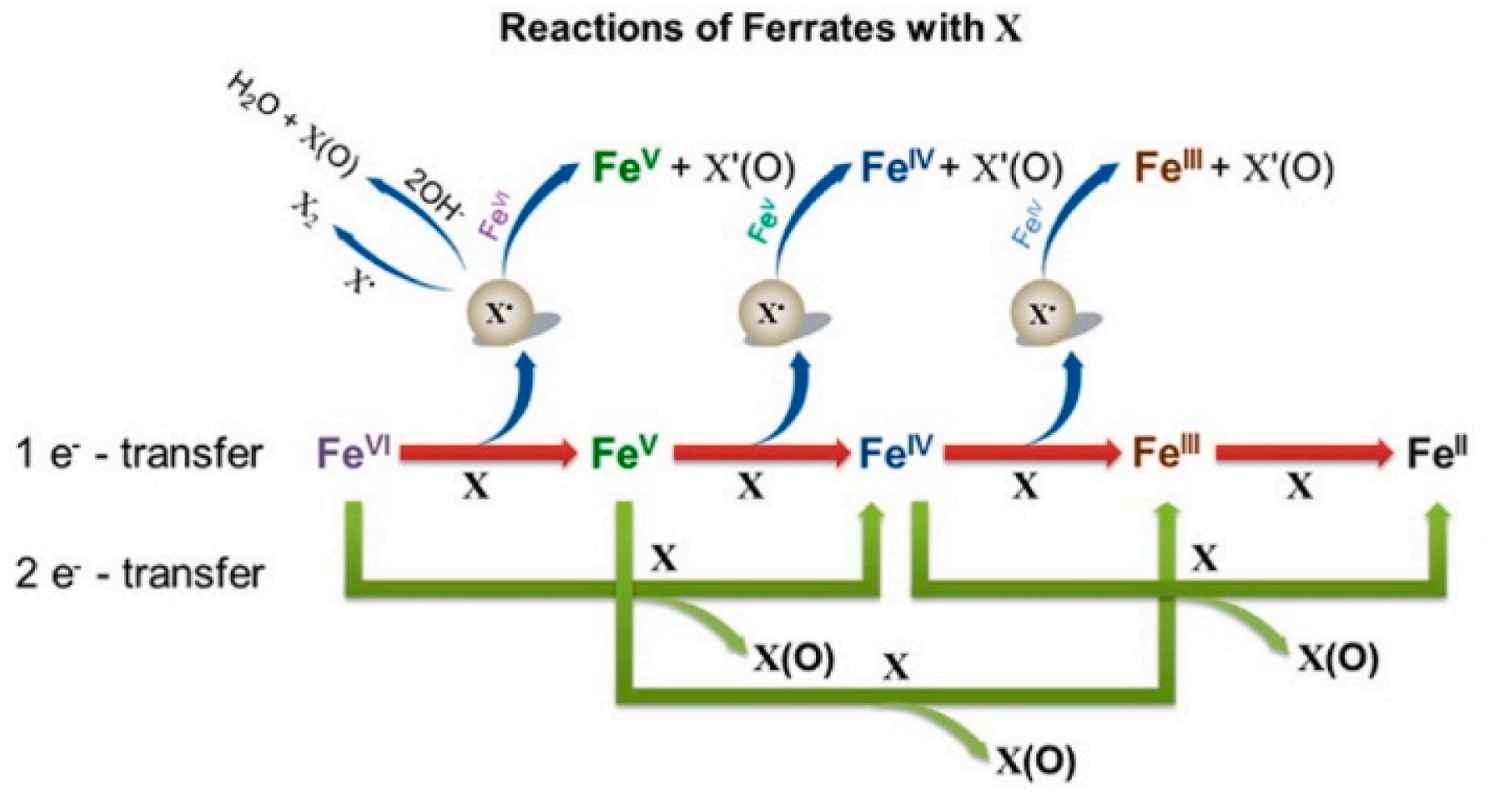

Self-Decay of Ferrates

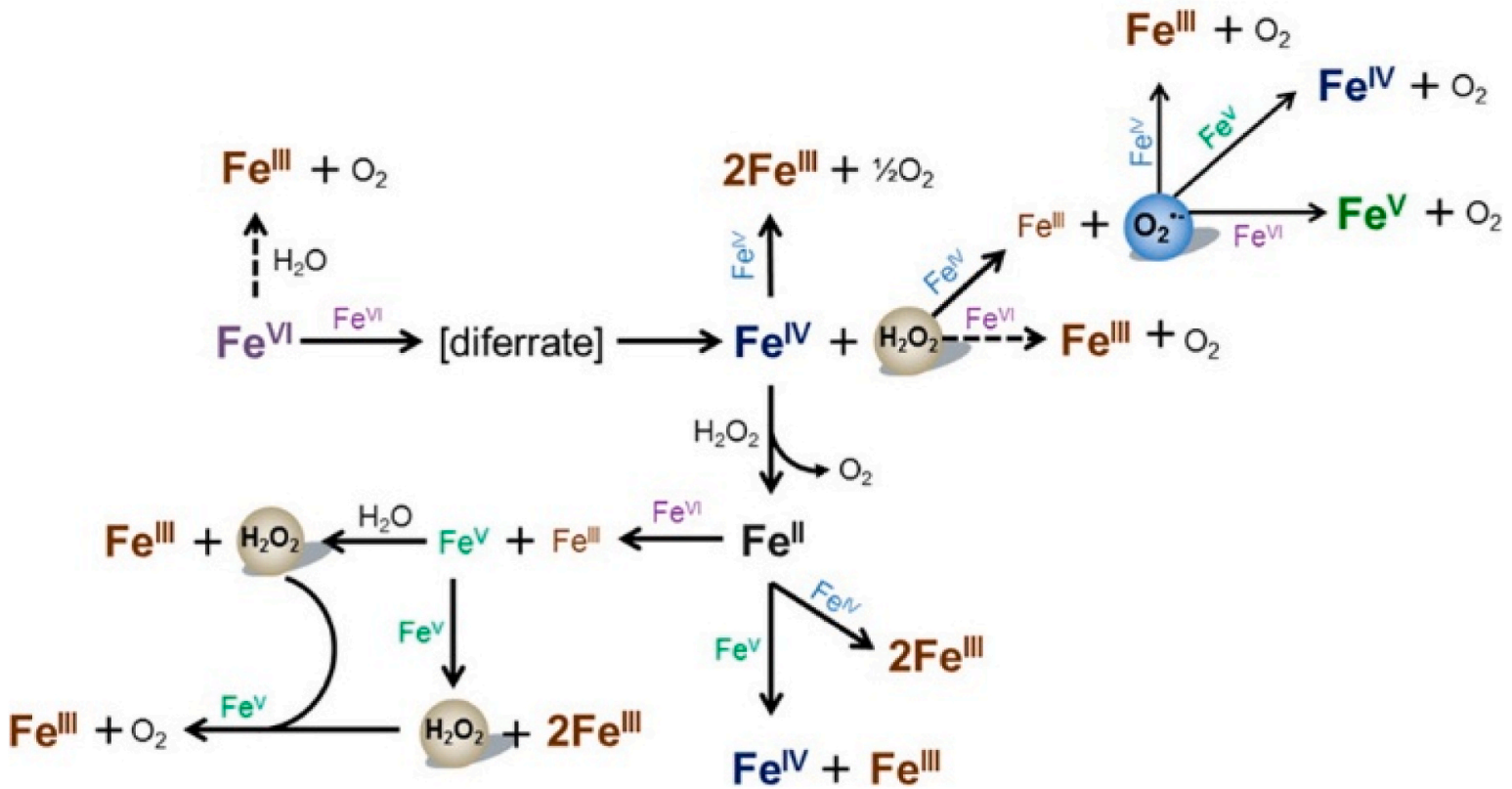

Fig. 1. Possible reaction steps of Ferrate oxidation compound (x) (Lee et al., 2004).

$\mathrm{Fe}(\mathrm{VI})$ can react with organic contaminants as follows:

(i) $\mathrm{Fe}(\mathrm{V}) \& \mathrm{Fe}(\mathrm{IV})$ leads additional reactions to organic pollutants.

(ii) $\mathrm{Fe}(\mathrm{VI}), \mathrm{Fe}(\mathrm{V})$ and $\mathrm{Fe}(\mathrm{IV})$ self-decomposition of organisms.

(iii) Reactive oxygen species including $\left(\cdot \mathrm{O}_{2}-\right.$, and $\mathrm{H}_{2} \mathrm{O}_{2}$ generated from self-degradation/decompositions (e.g., $\mathrm{Fe}(\mathrm{VI})+\mathrm{Fe}(\mathrm{II}) \rightarrow \mathrm{Fe}$ (V) $+\mathrm{Fe}(\mathrm{III})$ and $\left.\mathrm{Fe}(\mathrm{II}) / \mathrm{Fe}(\mathrm{III})+\mathrm{O}_{2} / \mathrm{H}_{2} \mathrm{O}_{2} \rightarrow \mathrm{Fe}(\mathrm{IV}) / \mathrm{Fe}(\mathrm{V})\right)$ (Sharma et al., 2015).

\section{Recent advancement of ferrate}

There are number of methods elucidated in the last forty-five years. Some of them belong to sustained-release (single and multiple-dose), insitu activation (encapsulated, activation by reagent and UV); detail of these is given in Fig. 5. The mentioned data in Fig. 5, is extracted from the web of science on 06-June-2021.

\subsection{Catalytic activation of $\mathrm{Fe}(\mathrm{VI})$}

The oxidative capability of $\mathrm{Fe}(\mathrm{VI})$ was extremely reliant on $\mathrm{pH}$, water nature/constituents, and contamination level (Feng et al., 2016). Fe(VI) amplification or catalysis has recently been put forward to improve the oxidation of organic contaminants (Feng and Sharma, 2018) (Manoli et al., 2017a) (Sun et al., 2019). For example, acid activation of Fe(VI) (e.g. $\mathrm{HCl}$ ) may facilitate the oxidative transition to the development of the intermediate iron species ( $\mathrm{Fe}(\mathrm{V}) / \mathrm{Fe}$ (IV))) of micropollutants (Ghosh et al., 2019; Manoli et al., 2017b). The radical sulphate and hydroxy radical were the major oxidants in a detailed analysis during the $\mathrm{Fe}(\mathrm{VI})$ /per-oxymonosulfate reaction (Wu et al., 2018). The agents that inhibit one and two electrons showed accelerated ferrate (VI) toxin 
Phenoxy radical reaction:<smiles>CC(C)c1cc(Br)c(O)c(Br)c1</smiles><smiles>CC(C)c1cc(Br)c(O)c(Br)c1</smiles><smiles>CC(C)(C)c1cc(Br)c(O)c(Br)c1</smiles><smiles>CC(C)C1=CC(Br)C(=O)C(Br)=C1</smiles><smiles>CC(C)c1cc(Br)c(O)c(I)c1</smiles><smiles>C[C+](C)c1cc(Br)c(O)c(Br)c1</smiles>

Substitution:<smiles>C[C+](C)c1cc(Br)c(O)c(Br)c1</smiles><smiles>CC(C)(O)c1cc(Br)c(O)c(Br)c1</smiles><smiles>C[C+](C)c1cc(Br)c(O)c(Br)c1</smiles><smiles>CO</smiles><smiles>COC(C)(C)c1cc(Br)c(O)c(Br)c1</smiles>

Fig. 2. Projected reaction pattern for oxidation of tetrabromobisphenol A by Fe (VI) (Yang et al., 2014).

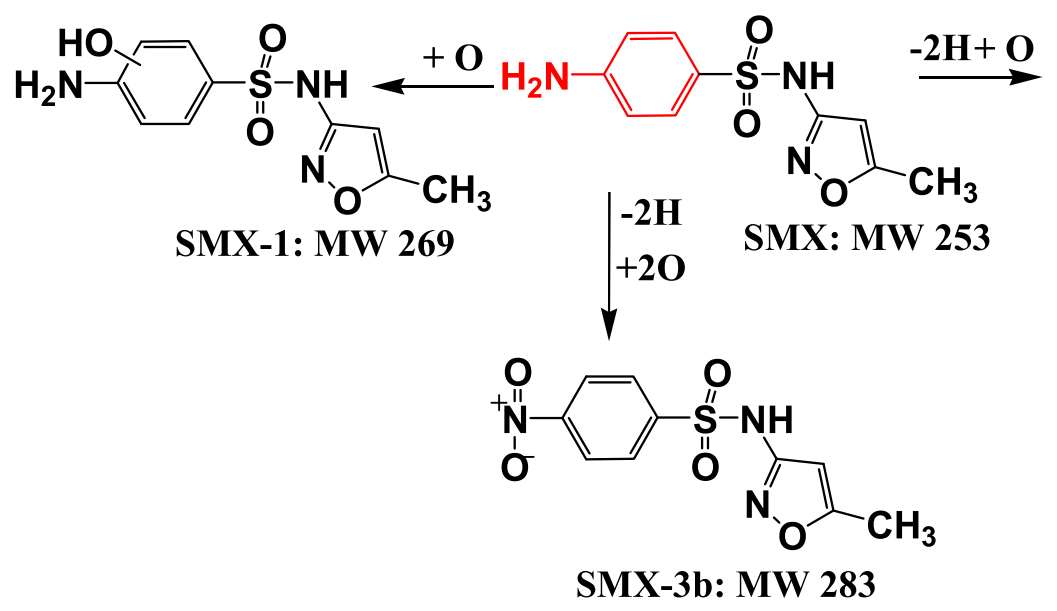

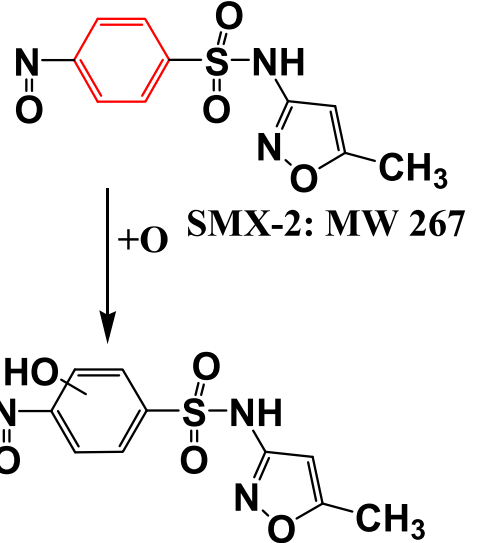

SMX-3a: MW 283

Fig. 3. Reaction degradation pathways of sulfamethoxazole by Fe (VI) (Zhou and Jiang, 2015b).

oxidation in the 30s. In general, there is limited information regarding activation by $\mathrm{Fe}(\mathrm{VI})$, yet efficient methods for growing $\mathrm{Fe}(\mathrm{VI})$ oxidation still need to be developed (Feng et al., 2018). Recent advancements elucidating the different activation agents to activate $\mathrm{Fe}(\mathrm{VI})$ are presented in Table 3. Carbonaceous materials act as emerging UV catalyst, which help Fe(VI) by generating electron, which couple with Fe(VI) and produce synergistic effects. Besides, carbonaceous material act as absorber which may help to ferrate for greater stability (Ali et al., 2020; Wang and Hu, 2014). This is very obvious and reported that Fe(VI) generates one or two electron, these generated electron contribute with electron produced by UV, and synergistically they contribute for comprehensive degradation. 


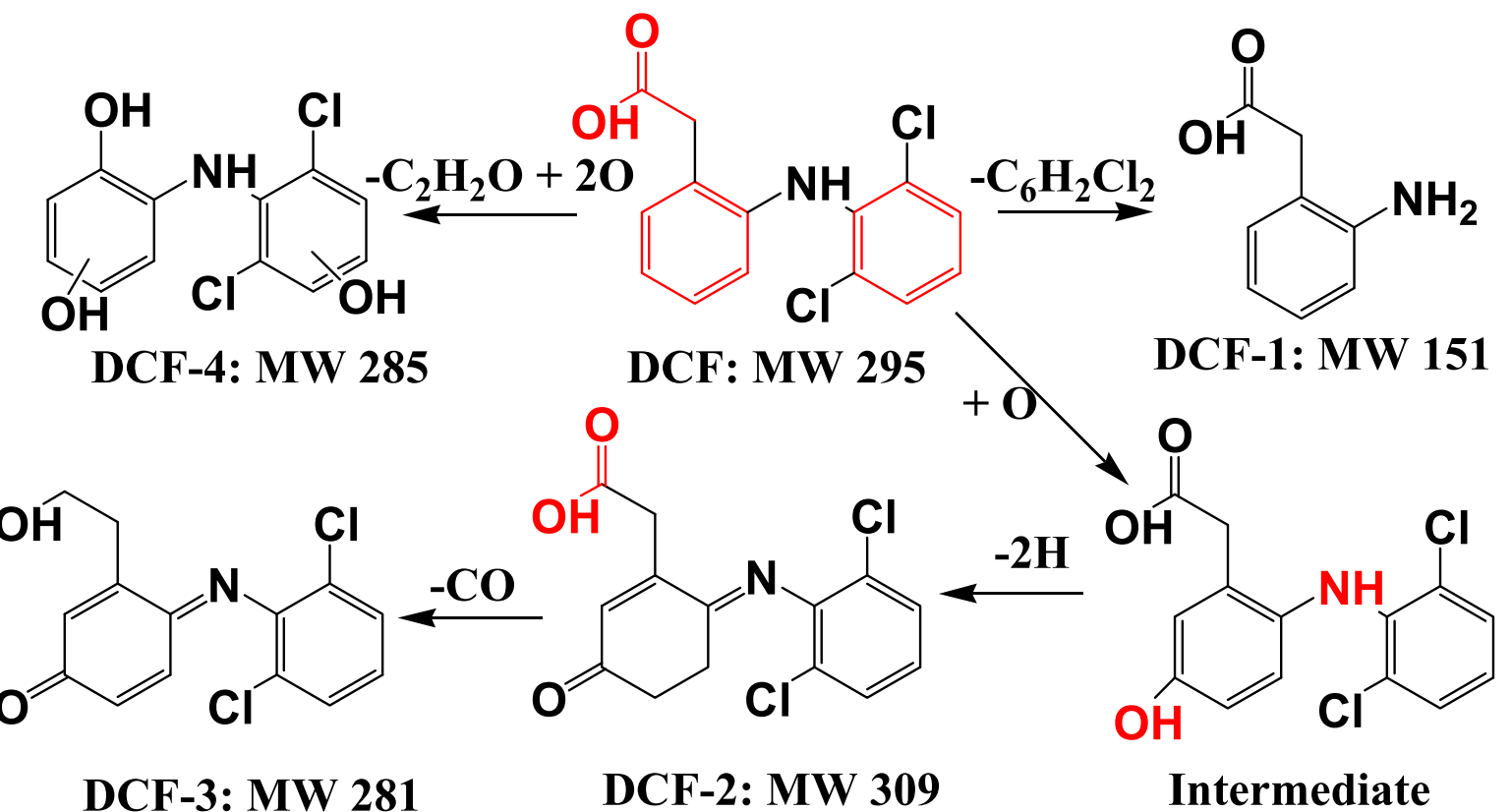

Fig. 4. Reaction degradation pathway of diclofenac by Fe (VI) (Zhou and Jiang, 2015b).

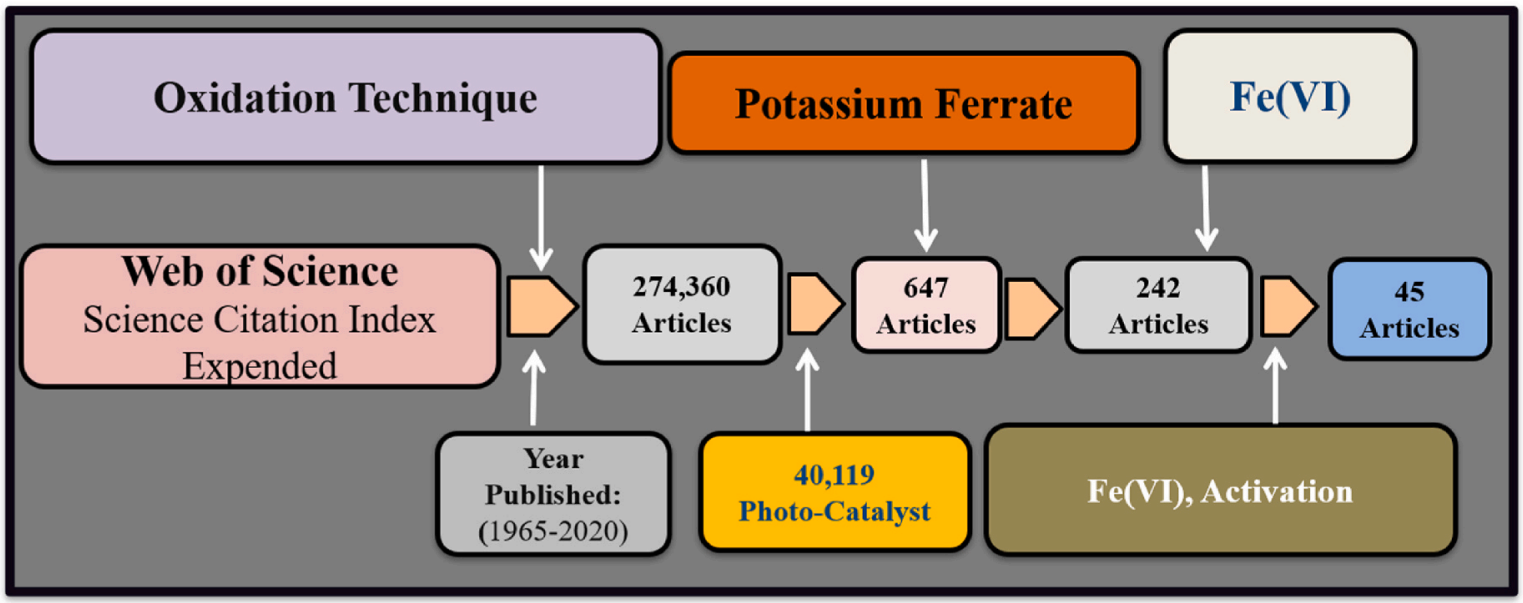

Fig. 5. Recent advancement in ferrate oxidation from 1965 to 2020.

\subsubsection{Catalytic oxidation of ferrate by using ultraviolet light}

Through UV light, Fe(VI) reduction was achieved with the consecutive formation of the single-electron transfer point, $\mathrm{Fe}(\mathrm{V}), \mathrm{Fe}(\mathrm{IV})$ and $\mathrm{Fe}(\mathrm{III})$. In comparison, the redox potential of Fe(III) and Fe(V) are more higher than $\mathrm{Fe}(\mathrm{VI})$ (Sharma et al., 2013). Photocatalysis was proposed as an eco-friendly and efficient process, to increase the oxidation capacity of $\mathrm{Fe}(\mathrm{VI})$ for organic pollutants (Chen et al., 2015) (Luo et al., 2019; Matafonova and Batoev, 2018) (Talaiekhozani et al., 2016). These studies suggested that $\mathrm{Fe}(\mathrm{V})$, a Fe(VI) reduction agent through ultraviolet light, may be the most reactive species. In addition to $\mathrm{Fe}(\mathrm{V})$, active $\mathrm{UV} / \mathrm{Fe}(\mathrm{VI})$ oxidation species were also inferred from ${ }^{\circ} \mathrm{OH}$ (Aslani et al., 2017).

The degradation pathways of UV oxidation have been in the following sequence: UV/Fe(VI) $>\mathrm{UV} /$ chlorinated $>\mathrm{UV} / \mathrm{H}_{2} \mathrm{O}_{2}>\mathrm{UV} / \mathrm{PS}$ $>\mathrm{UV} / \mathrm{TiO}_{2}>\mathrm{UV} / \mathrm{PMS}$. The UV/PMS, UV/TiO 2 methods and UV/PS methods were poorly prepared for the degradation phase, and the UV/ E2 (estradiol) phase displayed mild degradation, whereas the phase of degradation was greatly increased by UV/chlorine process (Chuang et al., 2019; Mboula et al., 2015). The new technique for water purification can therefore be established UV/Fe (VI) oxidation. The general proposed reaction mechanism is given in Eq. 6 to Eq. 12. The generated radical in the below equations will facilitate the $\mathrm{Fe}(\mathrm{VI})$ process.

Photocatalyst $+\mathrm{hv} \rightarrow \mathrm{h}_{\mathrm{vb}}{ }^{+}+\mathrm{e}_{\mathrm{cb}}{ }^{-} \quad$ Eq.6

$\mathrm{O}_{2}+\mathrm{e}_{\mathrm{cb}}{ }^{-} \rightarrow \mathrm{O}_{2}{ }^{-}$

Eq.7

$\mathrm{O}_{2}^{\bullet^{-}}+\mathrm{H}^{+} \rightarrow \mathrm{HO}_{2} \cdot$

Eq.8

$\mathrm{O}_{2}{ }^{-}+\mathrm{e}_{\mathrm{cb}}{ }^{-}+2 \mathrm{H}_{2} \mathrm{O} \rightarrow \mathrm{H}_{2} \mathrm{O}_{2}+2 \mathrm{OH}^{-}$

Eq.9

$\mathrm{O}_{2}{ }^{-}+\mathrm{O}_{2}{ }^{-}+2 \mathrm{H}_{2} \mathrm{O} \rightarrow \mathrm{H}_{2} \mathrm{O}_{2}+\mathrm{O}_{2}+2 \mathrm{OH}^{-}$Eq.10

$\mathrm{H}_{2} \mathrm{O}_{2}+\mathrm{e}_{\mathrm{cb}}{ }^{-} \rightarrow \cdot \mathrm{OH}+\mathrm{OH}^{-}$

Eq.10

$\mathrm{O}_{2}{ }^{--}+\cdot \mathrm{OH} \rightarrow{ }^{1} \mathrm{O}_{2}+\mathrm{OH}^{-}$

Eq.11

$\mathrm{O}_{2}{ }^{\bullet-} /{ }^{1} \mathrm{O}_{2}+\mathrm{X} \rightarrow$ Product(s)

Eq.12 
Table 3

Activated $\mathrm{Fe}(\mathrm{VI})$ treatment performance for the degradation of different organic pollutants, including pharmaceuticals.

\begin{tabular}{|c|c|c|c|c|c|c|c|}
\hline $\begin{array}{l}\text { Sr } \\
\text { No. }\end{array}$ & Compound name & Activation agent & $\begin{array}{l}\text { Incubation } \\
\text { time }\end{array}$ & $\begin{array}{l}\text { Optimal pH } \\
\text { and reaction } \\
\text { temperature }\end{array}$ & Reaction condition & Results & Reference \\
\hline 1 & Carbamazepine (CBZ) & $\begin{array}{l}\mathrm{K}_{2} \mathrm{FeO}_{4} \text { with } \\
\text { carbonaceous } \\
\text { materials }\end{array}$ & $30 \mathrm{~min}$ & $\begin{array}{l}\text { pH: } 9.0 \text {, } \\
\text { time: } 25 \pm \\
1{ }^{\circ} \mathrm{C}\end{array}$ & $\begin{array}{l}\mathrm{Fe}^{\mathrm{VI}} \mathrm{O}_{4}{ }^{2-} \text { in the presence of } \\
\text { five carbonaceous materials } \\
\text { (C.M.s) (i.e., G.O., hydrochar, } \\
\text { rGO, graphite, and fullerene) }\end{array}$ & Removal efficiency; $30 \%$ & $\begin{array}{l}\text { Pan et al. } \\
(2020 a)\end{array}$ \\
\hline 2 & DCF (2,6- dichlorophenyl) & $\begin{array}{l}\text { Hydrochar and } \\
\text { graphene oxide }\end{array}$ & $30 \mathrm{~min}$ & $\begin{array}{l}\text { pH: 9.0, time: } \\
25 \pm 1{ }^{\circ} \mathrm{C}\end{array}$ & $\begin{array}{l}\mathrm{Fe}^{\mathrm{VI}} \mathrm{O}_{4}{ }^{2-} \text { in the presence of } \mathrm{G} . \\
\text { O. and hydrochar }\end{array}$ & N.A & $\begin{array}{l}\text { Pan et al. } \\
\text { (2020a) }\end{array}$ \\
\hline 3 & $\begin{array}{l}\text { TMP }[2,4 \text {-diamino-5- } \\
\left(3^{\prime}, 4^{\prime}, 5^{\prime} \text {-trimethoxybenzyl }\right) \\
\text { pyrimidine }]\end{array}$ & $\begin{array}{l}\text { Hydrochar and } \\
\text { graphene oxide }\end{array}$ & $30 \mathrm{~min}$ & $\begin{array}{l}\mathrm{pH}: 9.0 \text {, time: } \\
25 \pm 1{ }^{\circ} \mathrm{C}\end{array}$ & $\begin{array}{l}\mathrm{Fe}^{\mathrm{VI}} \mathrm{O}_{4}{ }^{2-} \text { in the presence of } \mathrm{G} \text {. } \\
\text { O. and hydrochar }\end{array}$ & N.A & $\begin{array}{l}\text { Pan et al. } \\
(2020 a)\end{array}$ \\
\hline 4 & Roxarsone & $\begin{array}{l}\text { Hematite/sulfite/ } \\
\text { light system and } \\
\text { PMSO as a probe } \\
\text { compound }\end{array}$ & $10 \mathrm{~min}$ & $\mathrm{pH}: 10 \pm 0.05$ & $\begin{array}{l}\mathrm{Fe}(\mathrm{IV} / \mathrm{V}) \text { oxidizes PMSO, } \\
\text { Xenon lamp with the } \\
\text { irradiation intensity of } 28.5 \\
\text { mWcm }^{-2}\end{array}$ & Removal efficiency $>80 \%$ & $\begin{array}{l}\text { Zhu et al. } \\
(2020)\end{array}$ \\
\hline 5 & $\begin{array}{l}\text { Cyanotoxin, microcystin-LR } \\
\text { (MC-LR) }\end{array}$ & $\mathrm{Fe}(\mathrm{VI}) \mathrm{UV} / \mathrm{H}_{2} \mathrm{O}_{2}$ & & $\begin{array}{l}\text { pH: } 7.5 \text { to } 8.1 \\
\text { at } 20{ }^{\circ} \mathrm{C}\end{array}$ & $\begin{array}{l}{[\mathrm{MC}-\mathrm{LR}]=3.33 \mu \mathrm{M} ;[\mathrm{Fe}(\mathrm{VI})]} \\
=66.6 \mu \mathrm{M}\end{array}$ & $\begin{array}{l}\text { Degradation efficiency } \\
>95 \%\end{array}$ & $\begin{array}{l}\text { Jiang et al. } \\
\text { (2014) }\end{array}$ \\
\hline 6 & $\begin{array}{l}\text { ABTS (2,2'-azino-bis(3- } \\
\text { ethylbenzothiazoline-6- } \\
\text { sulfonate) }\end{array}$ & $\begin{array}{l}\mathrm{Fe}(\mathrm{VI})-\mathrm{ABTS} \text { System } \\
\text { with } \mathrm{H}_{2} \mathrm{O}_{2}\end{array}$ & & pH: 7 & $\begin{array}{l}\text { ABTS }(80 \mu \mathrm{M}) \text { with Fe(VI) } \\
(2-24 \mu \mathrm{M}), \text { Applied } \\
\text { Photophysics SX-17 MV } \\
\text { stopped-flow } \\
\text { spectrophotometer }\end{array}$ & $\begin{array}{l}\text { It was observed that } \\
\text { degradation efficiency of } \\
\mathrm{Fe}(\mathrm{VI}) \text { is less than the } \\
\text { computed value. }\end{array}$ & $\begin{array}{l}\text { Lee et al. } \\
(2014)\end{array}$ \\
\hline 7 & $\begin{array}{l}\text { Trimethoprim (TMP), } \\
\text { naproxen (NAP), and } \\
\text { sulfonamide antibiotics } \\
\text { (SAs) }\end{array}$ & $\begin{array}{l}\text { Fe(VI) and S.A.s, } \\
\text { UV-vis }\end{array}$ & & $\begin{array}{l}\mathrm{pH}: \\
6.93-9.50 \\
\text { temp: } 25^{\circ} \mathrm{C}\end{array}$ & $\begin{array}{l}\mathrm{Fe}(\mathrm{VI}) 300 \mu \mathrm{M}, \mathrm{UV}-\mathrm{vis} \\
\text { spectrophotometer at } 390 \mathrm{~nm}\end{array}$ & $\begin{array}{l}\mathrm{Fe}(\mathrm{VI}) \text { is a capable oxidant } \\
\text { for the degradation of } \\
\text { pharmaceuticals in } \\
\text { hydrolyzed urine. }\end{array}$ & $\begin{array}{l}\text { Luo et al. } \\
\text { (2019) }\end{array}$ \\
\hline 8 & Carbamazepine & $\begin{array}{l}\mathrm{Fe}(\mathrm{VI}) \text { oxidation by } \\
\text { gamma radiation } \\
\text { source }\end{array}$ & $240 \mathrm{~min}$ & Temp: $25^{\circ} \mathrm{C}$ & $\begin{array}{l}\text { Co source was used to conduct } \\
\text { the experiments at the dose } \\
\text { rate of } 103 \mathrm{~Gy} / \mathrm{min} \text {. }\end{array}$ & $\begin{array}{l}\text { Decrease the adsorbed } \\
\text { dose, and enhance the } \\
\text { mineralization of } \\
\text { carbamazepine by } \\
\text { radiation }\end{array}$ & $\begin{array}{l}\text { Wilde et al. } \\
\text { (2013) }\end{array}$ \\
\hline 9 & $\begin{array}{l}\text { 2,4-dichlorophenol }(2,4- \\
\text { DCP) }\end{array}$ & $\mathrm{Fe}(\mathrm{VI}), \mathrm{UV} / \mathrm{PS}$ & $60 \mathrm{~min}$ & $\begin{array}{l}\mathrm{pH}: 3.0-6.0 \\
\text { temp: } \\
25 \pm 0.2{ }^{\circ} \mathrm{C}\end{array}$ & $\begin{array}{l}\text { UV lamps linked with } 15 \mathrm{~W} \\
\text { tubes }(185 \mathrm{~nm} \text {, each light } \\
\left.\text { intensity }=0.136 \mathrm{~mW} / \mathrm{cm}^{2}\right)\end{array}$ & $\begin{array}{l}\text { A innovative method for } \\
\text { pollutant degradation } \\
\text { using UV/Fe(VI) oxidation } \\
\text { and give new insights into } \\
\text { the oxidation mechanisms } \\
\text { and the degradation } \\
\text { efficiency reached } 73.0 \%\end{array}$ & $\begin{array}{l}\text { Wu et al. } \\
(2020 \mathrm{~b})\end{array}$ \\
\hline 10 & $\begin{array}{l}\text { Organic pollutants (DCF, } \\
\text { SMX, CIP, CBZ, and DEET) }\end{array}$ & $\begin{array}{l}\text { Fe(VI) activation by } \\
\text { biochar }\end{array}$ & $20 \min$ & $\begin{array}{l}\mathrm{pH}: 7-8 \text {, at } \\
\text { temp: } 25{ }^{\circ} \mathrm{C}\end{array}$ & $\begin{array}{l}\mathrm{Fe}(\mathrm{VI})(50 \mu \mathrm{M}) \text { magnetic } \\
\text { stirrer }(500 \mathrm{r} / \mathrm{min})\end{array}$ & $\begin{array}{l}\text { Removal efficiency } 75 \% \text { of } \\
\text { SMX, } 70 \% \text { of CBZ, } 97 \% \text { of } \\
\text { CIP, and } 65 \% \text { of DCF. }\end{array}$ & $\begin{array}{l}\text { Tian et al. } \\
(2020)\end{array}$ \\
\hline 11 & $\begin{array}{l}\text { Oxygen-evolution reaction } \\
\text { (OER) }\end{array}$ & $\mathrm{K}_{2} \mathrm{FeO}_{4}$ and $\mathrm{Ni}_{2} \mathrm{O}_{3}$ & $20 \min$ & pH:13.0 & $\begin{array}{l}\mathrm{Ni} \text { foam was operated at } 10.0 \\
\mathrm{~V}\end{array}$ & $\begin{array}{l}\text { The experiments showed } \\
\text { that } \mathrm{K}_{2} \mathrm{FeO}_{4} \text {, compared to } \\
\mathrm{Ni}_{2} \mathrm{O}_{3} \text {, is more active } \\
\text { toward OER. } \mathrm{K}_{2} \mathrm{FeO}_{4} \text { is not } \\
\text { stable in the presence of } \mathrm{Ni} \\
\text { (II) oxide }\end{array}$ & $\begin{array}{l}\text { Akbari et al. } \\
(2020) \text {. }\end{array}$ \\
\hline 12 & $\begin{array}{l}\text { Sulfamethoxazole, coliforms } \\
\text { and E.coli }\end{array}$ & $\mathrm{Fe}(\mathrm{VI})$ and ferric salts & & pH: 7.83 & $\begin{array}{l}\text { Spectrophotometrically } \\
\text { measured using the ABTS } \\
\text { method, } \mathrm{UV}_{254} \text { abs }\end{array}$ & $\begin{array}{l}\mathrm{Fe}(\mathrm{VI}) \text { in the presence of } \mathrm{Fe} \\
\text { (III) was described to } \\
\text { hasten the degradation. }\end{array}$ & $\begin{array}{l}\text { Zheng et al., } \\
2020\end{array}$ \\
\hline 13 & Bypass wastewaters & $\begin{array}{l}\text { Fe(VI)- iron } \\
\text { electrocoagulation } \\
\text { system }\end{array}$ & $45 \mathrm{~min}$ & pH: 7.0-9.3 & $\begin{array}{l}\text { iron electrocoagulation } \\
\text { system used in the } \\
\text { experiments }\end{array}$ & $\begin{array}{l}\text { The experimental results } \\
\text { demonstrated the } \\
\text { synergetic effect of the } \\
\text { coupled processes for the } \\
\text { removal of COD from } \\
\text { bypass wastewater. }\end{array}$ & $\begin{array}{l}\text { Elnakar and } \\
\text { Buchanan } \\
(2020)\end{array}$ \\
\hline 14 & selenium pollution [Se(IV)] & $\begin{array}{l}\mathrm{K}_{2} \mathrm{FeO}_{4} \text {, ex-situ and } \\
\text { in-situ adsorption, }\end{array}$ & $\begin{array}{l}30-120 \\
\min \end{array}$ & $\begin{array}{l}\mathrm{pH}: 2.5-6.5 \text {, } \\
\text { temp: } 25^{\circ} \mathrm{C}\end{array}$ & $\begin{array}{l}\mathrm{K}_{2} \mathrm{FeO}_{4}(0.05 \mathrm{~g}) \text { with } 100 \mathrm{~mL} \\
\mathrm{Se}(\mathrm{IV}) \text { solutions shaken at } \\
200 \mathrm{rpm}\end{array}$ & Removal efficiency $>97 \%$ & $\begin{array}{l}\mathrm{Xu} \text { and } \mathrm{Fu} \\
(2020) \text {. }\end{array}$ \\
\hline 15 & $\begin{array}{l}\text { Ethynl-estradiol Estradiol } \\
\text { Bisphenol A }\end{array}$ & $\mathrm{FeO}_{4}{ }^{-2}$ & $30 \mathrm{~min}$ & $\begin{array}{l}\mathrm{pH}: 8 \text {, temp: } \\
25^{\circ} \mathrm{C}\end{array}$ & $\begin{array}{l}\text { Ferrate (VI) } 10 \text { and } 20 \mathrm{mgL}^{-1} \text {, } \\
\text { fast mixing at } 400 \mathrm{rpm} \text { for } 1 \\
\text { min after dosing, }\end{array}$ & Removal efficiency $>99 \%$ & $\begin{array}{l}\text { Lee et al. } \\
(2005) \text {. }\end{array}$ \\
\hline 16 & Benzophenone-3 & & & $\begin{array}{l}\mathrm{pH}: 8.0 \\
\text { temp: } 24 \pm \\
1{ }^{\circ} \mathrm{C}\end{array}$ & & Removal efficiency $>95 \%$ & $\begin{array}{l}\text { (Yang and Ying, } \\
\text { 2013) }\end{array}$ \\
\hline 17 & Triclosan (TCS) & & & $\begin{array}{l}\text { pH: } 7.0 \\
\text { temp: } 24 \pm \\
1{ }^{\circ} \mathrm{C}\end{array}$ & & Removal efficiency >95 \% & $\begin{array}{l}\text { (Yang and Ying, } \\
\text { 2013) }\end{array}$ \\
\hline 18 & Bisphenol A & $\mathrm{Fe}(\mathrm{VI})$ & $10 \mathrm{~min}$ & $\begin{array}{l}\mathrm{pH}: 7.0 \\
\text { temp: } 25^{\circ} \mathrm{C}\end{array}$ & $\begin{array}{l}\mathrm{Fe}(\mathrm{VI}) \text { to BPA }(0.1-8.0 \mathrm{M}) \text {, } \\
\text { TUV detector set at } 280 \mathrm{~nm}\end{array}$ & $\begin{array}{l}\text { Removal efficiency }>97.5 \\
\%\end{array}$ & $\begin{array}{l}\text { Han et al. } \\
(2015)\end{array}$ \\
\hline 19 & Carbamazepine & $\begin{array}{l}\mathrm{Mn}(\mathrm{VII}) ; \mathrm{KMnO}_{4} \\
\text { And } \mathrm{Fe}(\mathrm{VI}) ; \mathrm{K}_{2} \mathrm{FeO}_{4}\end{array}$ & & $\begin{array}{l}\mathrm{pH}: 7.0 \\
\text { temp: } 25{ }^{\circ} \mathrm{C}\end{array}$ & $\begin{array}{l}3 \times 10^{2} \mathrm{M}^{-1} \mathrm{~s}^{-1} \text { for } \mathrm{Mn}(\mathrm{VII}) \\
\text { and } 70 \mathrm{M}^{-1} \mathrm{~s}^{-1} \text { for } \mathrm{Fe}(\mathrm{VI})\end{array}$ & N/A & Hu et al. (2009) \\
\hline 20 & Ciprofloxacin (CIP) & $\mathrm{K}_{2} \mathrm{FeO}_{4}$ & & & $\begin{array}{l}\text { Ferrate (VI) dose of } 1-5 \mathrm{mg} \\
\mathrm{L}^{-1}\end{array}$ & Removal efficiency $>70 \%$ & $\begin{array}{l}\text { Zhou and Jiang } \\
\text { (2015a) }\end{array}$ \\
\hline
\end{tabular}




\begin{tabular}{|c|c|c|c|c|c|c|c|}
\hline $\begin{array}{l}\text { Sr } \\
\text { No. }\end{array}$ & Compound name & Activation agent & $\begin{array}{l}\text { Incubation } \\
\text { time }\end{array}$ & $\begin{array}{l}\text { Optimal } \mathrm{pH} \\
\text { and reaction } \\
\text { temperature }\end{array}$ & Reaction condition & Results & Reference \\
\hline & & & & $\begin{array}{l}\mathrm{pH}: 8.0 \\
\text { temp: } 20 \pm \\
2{ }^{\circ} \mathrm{C}\end{array}$ & & & \\
\hline 21 & Diclofenac & & & $\begin{array}{l}\mathrm{pH}: 7.0 \\
\text { temp:23 } \\
2{ }^{\circ} \mathrm{C}\end{array}$ & & Removal efficiency >99\% & $\begin{array}{l}\text { Chiu et al. } \\
\text { (2016) }\end{array}$ \\
\hline 22 & Naproxen & & & $\begin{array}{l}\mathrm{pH}: 7.0,0 \\
\text { temp: } 23 \pm \\
2{ }^{\circ} \mathrm{C}\end{array}$ & & $\begin{array}{l}\text { Removal efficiency }>99.9 \\
\%\end{array}$ & $\begin{array}{l}\text { Chiu et al. } \\
\text { (2016) }\end{array}$ \\
\hline 23 & Flurbiprofen & $\mathrm{Fe}(\mathrm{VI}): \mathrm{UV}$ & 20 min. & $\begin{array}{l}\mathrm{pH}: 4.0 \\
\text { temp: } 25{ }^{\circ} \mathrm{C}\end{array}$ & $\begin{array}{l}\text { UV-VIS spectrophotometer at } \\
\text { the wavelength of } 247 \mathrm{~nm}\end{array}$ & Removal efficiency >99 \% & $\begin{array}{l}\text { Barisci et al. } \\
\text { (2015) }\end{array}$ \\
\hline 24 & Ibuprofen & $\mathrm{FeO}_{4}{ }^{-2}$ oxidant & & $\begin{array}{l}\text { pH: } 8.0, \\
\text { temp: } 25{ }^{\circ} \mathrm{C}\end{array}$ & & $\begin{array}{l}\text { Removal efficiency up to } \\
40 \%\end{array}$ & $\begin{array}{l}\text { Sharma and } \\
\text { Mishra (2006) }\end{array}$ \\
\hline 25 & Octylphenols & $\mathrm{Fe}(\mathrm{VI})$ oxidation & & $\begin{array}{l}\mathrm{pH}: 7.0 \\
\text { temp: } 25{ }^{\circ} \mathrm{C}\end{array}$ & $\begin{array}{l}\text { Octylphenols conc. } \\
0.001-1.44 \mu \mathrm{g} \mathrm{L}^{-1}\end{array}$ & Effective results & $\begin{array}{l}\text { Sharma et al. } \\
\text { (2009) }\end{array}$ \\
\hline 26 & $\begin{array}{l}\text { Nonylphenol (N.P.), and } \\
\text { bisphenol-A (BPA) }\end{array}$ & $\mathrm{Fe}(\mathrm{VI})$ oxidation & & $\begin{array}{l}\mathrm{pH}: 7.0 \\
\text { temp: } 25^{\circ} \mathrm{C}\end{array}$ & $\begin{array}{l}0.006-32.8 \text {, and } 0.0005-4.0 \\
\mu \mathrm{gL}^{-1} \text { for NP, and BPA } \\
\text { respectively }\end{array}$ & Maximum degradation & $\begin{array}{l}\text { Sharma et al. } \\
(2009)\end{array}$ \\
\hline 27 & Sulfamethoxazole & $\mathrm{K}_{2} \mathrm{FeO}_{4}$ & & $\begin{array}{l}\mathrm{pH}: 7.0-9.5 \\
\text { temp: } 25^{\circ} \mathrm{C}\end{array}$ & $10 \mathrm{mgL}^{-1} \mathrm{~K}_{2} \mathrm{FeO}_{4}$ & N/A & $\begin{array}{l}\text { Noorhasan } \\
\text { et al. ( } 2010)\end{array}$ \\
\hline 28 & Glycylglycine & $\mathrm{K}_{2} \mathrm{FeO}_{4}$ & & $\begin{array}{l}\mathrm{pH}: 9.5 \\
\text { temp: } 25^{\circ} \mathrm{C}\end{array}$ & $10 \mathrm{mgL}^{-1} \mathrm{~K}_{2} \mathrm{FeO}_{4}$ & & $\begin{array}{l}\text { Noorhasan } \\
\text { et al. (2010) }\end{array}$ \\
\hline 29 & Glycine & $\mathrm{K}_{2} \mathrm{FeO}_{4}$ & & $\begin{array}{l}\mathrm{pH}: 9.5 \\
\text { temp: } 25{ }^{\circ} \mathrm{C}\end{array}$ & $10 \mathrm{mgL}^{-1} \mathrm{~K}_{2} \mathrm{FeO}_{4}$ & & $\begin{array}{l}\text { Noorhasan } \\
\text { et al. (2010) }\end{array}$ \\
\hline 30 & $\begin{array}{l}\text { PPCPs and EDCs noted in } \\
\text { secondary effluents of } \\
\text { WWTPs }\end{array}$ & $\mathrm{Fe}(\mathrm{VI})$ oxidation & & $\begin{array}{l}\text { pH:7.0, } \\
\text { temp: } 23 \pm \\
2{ }^{\circ} \mathrm{C}\end{array}$ & $\mathrm{Fe}(\mathrm{VI})$ dose $0-10 \mathrm{mg} \mathrm{L}^{-1}$ & $\begin{array}{l}31 \text { PPCPs and EDCs noted } \\
\text { in secondary effluents. }\end{array}$ & $\begin{array}{l}\text { Yang et al. } \\
\text { (2012) }\end{array}$ \\
\hline 31 & Sulfonamides (SNs) & Fe(VI) with UV & $5 \mathrm{~min}$ & pH: 7.0 & $\begin{array}{l}15 \mathrm{mg} \mathrm{L}^{-1} \mathrm{SNs}, \mathrm{UV} / \mathrm{Vis} \\
\text { spectrometer (UV-1600PC } \\
\text { VWR) at a wavelength of } 510 \\
\mathrm{~nm} \text { for Fe (VI) detection }\end{array}$ & Removal efficiency: $100 \%$ & $\begin{array}{l}\text { Acosta-Rangel } \\
\text { et al. (2020). }\end{array}$ \\
\hline 32 & trimethoprim (TMP) & $\mathrm{Fe}(\mathrm{VI}) / \mathrm{UV}$-visible & & $\begin{array}{l}\mathrm{pH}: 9.0 \\
\text { temp: } 25^{\circ} \mathrm{C}\end{array}$ & $\begin{array}{l}510 \mathrm{~nm} \text { using UV-visible } \\
\text { spectrophotometer }\end{array}$ & $\begin{array}{l}\mathrm{Fe}(\mathrm{VI}) \text { would increase for } \\
\text { complete removal of TMP } \\
\text { from the secondary } \\
\text { effluent water }\end{array}$ & $\begin{array}{l}\text { Anquandah } \\
\text { et al. (2011) }\end{array}$ \\
\hline 33 & $\begin{array}{l}\text { Polychlorinated diphenyl } \\
\text { sulfides (PCDPSs) }\end{array}$ & Fe(VI) oxidation & & pH: 8.0 & $\begin{array}{l}\mathrm{Fe}(\mathrm{VI}) \text { stock solution to } 30 \mathrm{~mL} \\
\text { of } 20.0 \mathrm{mM} \text { PCDPSs solution }\end{array}$ & $\begin{array}{l}\text { Degradation of PeCDPS by } \\
\text { Fe(VI) achieved with the } \\
\text { loss toxicity from the } \\
\text { parent compound. }\end{array}$ & $\begin{array}{l}\text { Chen et al. } \\
\text { (2018) }\end{array}$ \\
\hline 34 & Cetylpyridinium chloride & UV/Fe(VI) oxidation & & pH: 9.2 & $\begin{array}{l}\text { UV-1601PC } \\
\text { spectrophotometer at } 510 \mathrm{~nm} \\
\text { wavelength. }\end{array}$ & Removal efficiency >95 \% & $\begin{array}{l}\text { Eng et al. } \\
(2006)\end{array}$ \\
\hline 35 & $\begin{array}{l}\text { Flumequine (FLU), } \\
\text { fluoroquinolone (FQ), } \\
\text { norfloxacin (NOR), } \\
\text { enrofloxacin (ENR), } \\
\text { marbofloxacin (MAR), and } \\
\text { ofloxacin (OFL)) }\end{array}$ & $\mathrm{Fe}(\mathrm{VI})$ & $2 \mathrm{~min}$ & pH: 7.0 & {$[\mathrm{Fe}(\mathrm{VI})]:[\mathrm{FQ}] \leq 20.0$} & Removal efficiency $85 \%$ & $\begin{array}{l}\text { Feng et al. } \\
(2016)\end{array}$ \\
\hline 36 & $\begin{array}{l}\text { Metal Cyanides }\left(\mathrm{K}_{2}[\mathrm{Zn}(\mathrm{C} .\right. \\
\left.\text { N.) })_{4}\right], \mathrm{K}_{2}\left[\mathrm{Cd}(\mathrm{C} . \mathrm{N} .)_{4}\right], \mathrm{K}_{2}[\mathrm{Ni} \\
\left.\text { (C.N.) })_{4}\right] \text {, and } \mathrm{K}_{3}\left[\mathrm{Cu}(\mathrm{C} . \mathrm{N} .)_{4}\right]\end{array}$ & $\mathrm{Fe}(\mathrm{VI})$ & & pH: 9.0 & $\begin{array}{l}\text { Solid } \mathrm{K}_{2} \mathrm{FeO}_{4} \text { was added to } \\
\text { solutions }(10 \mathrm{~mL}) \text { of } 0.1 \mathrm{~m} \\
\text { cyanides }\end{array}$ & $\begin{array}{l}\mathrm{Fe}(\mathrm{VI}) \text { has high } \\
\text { degradation potential for } \\
\mathrm{Cd}, \mathrm{Zn} \text {, and } \mathrm{Cu} \text { ion while } \\
\text { lower for Ni ions. }\end{array}$ & $\begin{array}{l}\text { Filip et al. } \\
\text { (2011) }\end{array}$ \\
\hline 37 & $\begin{array}{l}\text { Organic contaminants } \\
\text { (DEET, phenol, TMP, and } \\
\text { FLU) }\end{array}$ & $\begin{array}{l}\mathrm{Fe}(\mathrm{VI}) / \text { sulfite and } \mathrm{Fe} \\
(\mathrm{VI}) / \text { thiosulfate e } \\
\text { (PMSO) }\end{array}$ & & pH:9.0 & & $\begin{array}{l}\text { PMSO degradation } \\
\text { efficiency in sulfite } \\
\text { presence } \sim 90 \% \text {, while } \\
\text { negligible with } \mathrm{Fe}(\mathrm{VI}) \\
\text { alone. }\end{array}$ & $\begin{array}{l}\text { Gao et al. } \\
(2020)\end{array}$ \\
\hline 38 & $\begin{array}{l}\text { Acesulfame potassium } \\
\text { (ACE) }\end{array}$ & $\mathrm{Fe}(\mathrm{VI})$ & $240 \mathrm{~min}$ & pH:7.6-8.1 & $\begin{array}{l}{[\mathrm{Fe}(\mathrm{VI})]:[\mathrm{ACE}], \text { molar ratio }} \\
6.0 \mathrm{M}\end{array}$ & Removal efficiency; $67 \%$ & $\begin{array}{l}\text { Ghosh et al. } \\
\text { (2019) }\end{array}$ \\
\hline 39 & Azo dye $\mathrm{X}-3 \mathrm{~B}$ & $\mathrm{Fe}(\mathrm{VI})$ & & $\mathrm{pH}: 9.0,60^{\circ} \mathrm{C}$ & & $\begin{array}{l}\text { Removal/decolorizing } \\
\text { efficiency }>80 \%\end{array}$ & $\begin{array}{l}\text { Han et al. } \\
\text { (2013) }\end{array}$ \\
\hline 40 & Produced water (PW) & $\mathrm{Fe}(\mathrm{VI})$ & $5-90 \mathrm{~min}$ & $\mathrm{pH}: 1-7.0$ & $\mathrm{Fe}^{6+}$ dosage of $1-25 \mathrm{mg} \mathrm{L}^{-1}$ & $\begin{array}{l}\text { Promising method for the } \\
\text { degradation of organic } \\
\text { compounds in produced } \\
\text { water }\end{array}$ & $\begin{array}{l}\text { Haneef et al. } \\
(2020)\end{array}$ \\
\hline
\end{tabular}

\section{Ferrate application for the degradation of micro pollutant (pharmaceuticals)}

In recent years, a lot of focus has been paid to the incidence of micro pollutants in water. Unrestricted toxins, which include endocrine disrupters, pharmaceutical, and personal care products (PPPs), have traditionally been referred to as environmental contaminants (Picó and Barceló, 2015). The growing use of pharmaceutical products globally and eventually in waste water is a problem (Jiang et al., 2013; Khetan and Collins, 2007). Through water treatment, many of these 
pharmaceuticals are not completely removed, and industrial waste is normally distributed directly into surface sources. Therefore in the marine world, pharmaceuticals are also found (Banjac et al., 2015; Evgenidou et al., 2015). Case studies of water supply, freshwater, and water medicines include Germany's conjugating x-ray (ICM) newspapers, Canadian and U.S. medicines, narcotics in Australia, and many other pharmaceutical molecules in the European Union, China, and the United States reported presence of pharmaceuticals (Michael et al., 2013; Postigo and Richardson, 2014). The presence of pharmaceuticals in numerous rivers will place marine life and environmental lives in danger (Cizmas et al., 2015; Gan et al., 2015). Advanced oxidation techniques are effective but have some disadvantages in the removal of drugs (Huber et al., 2005a; Huber et al., 2005b). For example, water chlorination has also been known to generate toxic chlorinated whilst also-products of decontamination (Gan et al., 2015; Sharma et al., 2014a). The ability to shape carcinogenic chlorite/bromate complexes is chlorine dioxide with ozone. The use of chloramine will contribute to nitrosamine production (Krasner et al., 2013; Sharma et al., 2011).

In contrast, in the renewable diagnostic process, $\mathrm{Fe}(\mathrm{VI})$ has arisen as an environmentally friendly oxidant. Several scientists are actively researching micropollutant oxidative removals, including pharmaceutical, by using Fe(VI) (Jiang et al., 2007; Lee et al., 2009; Sharma et al., 2008). A collection of pharmaceutical drugs treated using $\mathrm{Fe}(\mathrm{VI})$ as an oxidizing agent (Li et al., 2008). The compounds analysed include endocrine disfunction (sulfonamides, $\beta$ lactams, fluoroquinolones, trimethoprime, triclosants), $\beta$-blocking substances (Atenolol, metoprolol, propranololol, analgesic (diazepam), anti-carcinogenic substances (diclofenac and ibuprofen) and x-ray comparison medium (ditrizoic acid), anticonvulsants (Tramadol), and co-inflammatory substances (diclofenac and ibuprofen) (Sharma et al., 2014b). The thermodynamic properties of the reactions among $\mathrm{Fe}(\mathrm{VI})$ and certain molecules, as depicted by $\mathrm{X}$, are accompanied by the kinetics of the second order, given in Eq.13.

$-\mathrm{d}[$ Ferrate $] / \mathrm{dt}=\mathrm{k}_{\mathrm{app}}[$ Ferrate $][\mathrm{X}]$

Eq 13

where $\mathrm{k}_{\mathrm{app}}$ is the obvious variable of the second-order scale, [Ferrate] and $[\mathrm{X}]$ are simultaneously, $\mathrm{Fe}(\mathrm{VI})$ and medicinal concentrations. $\mathrm{K}_{\mathrm{app}}$ values were calculated for these reactions at various $\mathrm{pHs}$. In general, $\mathrm{pH}$ declines from neutral to alkaline conditions are indicated. The $\mathrm{pH}$ responsive rate reduction pattern was consistent with multiple reactions of ferrate reduction agents (Casbeer et al., 2013; Noorhasan et al., 2010). The pH-responsive rate reduction pattern was consistent with multiple reactions of $\mathrm{Fe}(\mathrm{VI})$ reduction agents (Hübner and Jekel, 2013; Karlesa et al., 2014; Wilde et al., 2013; Yang et al., 2012). Table 4 contains more information concerning each pharmaceutical type.

The kinetics of the reactions between $\mathrm{Fe}(\mathrm{VI})$ and alkyl phenol is examined with octylphenol, nonylphenol, bisphenol (BPA), and tetrabromobisphenol A (TBBPA) (Anquandah and Sharma, 2009; Li et al., 2008; Yang et al., 2014). For the removal of alkyl phenols in seconds, Fe (VI) reacted quickly with these phenols. The reaction materials for BPA and TBBPA oxidation have been tested (Han et al., 2015; Li et al., 2008; Yang et al., 2014). The production of oxidised materials is thus calculated as per the molar proportion and also relies on selective sedimentation of BPA to inorganic material. The ratio of molars to $\sim 30 \% \mathrm{DOC}$ was 4:1 ([ferrate]:[BPA])) (Li et al., 2008). DOC declining after complete oxidative transformation of BPA. by $\mathrm{Fe}(\mathrm{VI})$ have been calculated for oxidised product of BPA ( $\mathrm{Li}$ et al., 2008). The proposed reaction scheme displays nine known oxidised products (Li et al., 2008).

P-isoprophenyl, phenol, and 4-isopropanol phenol (1-phenyl-1butenyl) benzene were mildly toxic and present as reaction intermediate of BPA. This will lead to a disruption in the interaction between two phenyl groups. Styrene, 4-isopropyl-cyclohexa-2,5-dienone, p-hydroxylaceto-fenone, propane dioic acid, and oxalic acid can be oxidised by this precursor. Any compounds may have reacted with $\mathrm{Fe}(\mathrm{VI})$ to cause a partial $\mathrm{Fe}(\mathrm{VI})$ mineralization of BPA. Similar transformations of BPA/
Table 4

Apparently second-order reaction rates for Fe(VI) reactions of pharmaceuticals.

\begin{tabular}{|c|c|c|c|c|}
\hline Compound & Reactive agent & $\mathrm{pKa}$ & $\begin{array}{l}\mathrm{k}_{\mathrm{app}} \\
\text { (kinetic } \\
\text { rate } \\
\text { constant } \\
\text { of } \\
\text { pseudo } \\
\text { first- } \\
\text { order } \\
\text { reaction) }\end{array}$ & Reference \\
\hline Cimetidine & Ferrate & 6.9 & $\begin{array}{l}1.6 \\
( \pm 0.2) \times \\
10^{3}\end{array}$ & $\begin{array}{l}\text { (Nie et al., } \\
\text { 2020) }\end{array}$ \\
\hline Famotidine & Ferrate & 8.4 & $\begin{array}{l}7.8 \\
( \pm 0.3) \times \\
10^{2}\end{array}$ & $\begin{array}{l}\text { (Nie et al., } \\
\text { 2020) }\end{array}$ \\
\hline Sulfamethazine & Electrophoresis & $\begin{array}{l}2.3 \\
7.4\end{array}$ & $\begin{array}{l}158.7 \\
( \pm 5.8)\end{array}$ & $\begin{array}{l}\text { Lin et al. } \\
\text { (1997) }\end{array}$ \\
\hline Sulfamethoxazole & Ferrate & $\begin{array}{l}6.4 \\
( \pm 0.2) \\
7.8 \\
( \pm 0.3)\end{array}$ & $\begin{array}{l}55.7 \\
( \pm 8.1)\end{array}$ & $\begin{array}{l}\text { Kim et al. } \\
\text { (2015) }\end{array}$ \\
\hline Diclofenac & Ferrate & 4.2 & 32 & $\begin{array}{l}\text { Lee et al. } \\
(2009)\end{array}$ \\
\hline Carbamazepine & Ferrate & $\begin{array}{l}13.9 \\
\pm 0.2\end{array}$ & 16 & $\begin{array}{l}\text { Lee et al. } \\
\text { (2009) }\end{array}$ \\
\hline Trimethoprim & Ferrate & $\begin{array}{l}3.2 \\
7.2\end{array}$ & $\begin{array}{l}7.2 \\
( \pm 5.0)\end{array}$ & $\begin{array}{l}\text { (Qiang and } \\
\text { Adams, 2004; } \\
\text { Roth and } \\
\text { Strelitz, 1969) }\end{array}$ \\
\hline Atenolol & Ferrate & 9.6 & $\sim 7$ & $\begin{array}{l}\text { Lee and Von } \\
\text { Gunten (2010) }\end{array}$ \\
\hline Nalidixic acid & & 5.95 & $\begin{array}{l}2.6 \\
( \pm 0.4)\end{array}$ & $\begin{array}{l}\text { Ross and Riley } \\
\text { (1990) }\end{array}$ \\
\hline Ronidazole & $\begin{array}{l}\text { Activated } \\
\text { carbon }\end{array}$ & 1.32 & $\begin{array}{l}1.7 \\
( \pm 0.1)\end{array}$ & $\begin{array}{l}\text { Rivera-Utrilla } \\
\text { et al. (2009) }\end{array}$ \\
\hline Dimetridazole & $\begin{array}{l}\text { Activated } \\
\text { carbon }\end{array}$ & 2.81 & $\begin{array}{l}0.9 \\
( \pm 0.3)\end{array}$ & $\begin{array}{l}\text { Rivera-Utrilla } \\
\text { et al. (2009) }\end{array}$ \\
\hline Tinidazole & $\begin{array}{l}\text { Activated } \\
\text { carbon }\end{array}$ & 2.30 & $\begin{array}{l}0.2 \\
( \pm 0.1)\end{array}$ & $\begin{array}{l}\text { Rivera-Utrilla } \\
\text { et al. (2009) }\end{array}$ \\
\hline
\end{tabular}

intermediate products, including cleavage of $\mathrm{C}-\mathrm{C}$ bonding phenol, hydroquinone, benzoquinone, styrene, and low molecular weight dicarboxylic acids also have been identified by a later study of the oxidized product for $\mathrm{Fe}(\mathrm{VI})$ reaction with bisphenol-A (Han et al., 2015). The reaction pathways suggested in both experiments were also identical (Han et al., 2015; Li et al., 2008). The analysis of tetrabromobisphenol-A oxidation by $\mathrm{Fe}(\mathrm{VI})$ found that the target pollutant was quickly transformed with $\mathrm{Fe}(\mathrm{VI})$ (Yang et al., 2014). The existence of the inorganic ingredient metal oxides in the drinking water did not cause $\mathrm{Fe}(\mathrm{VI})$ oxidation for tetrabromobisphenol-A. However, organic fertilizer might compete with tetrabromobisphenol-A for $\mathrm{Fe}(\mathrm{VI})$, a typical constituent of tainted water. This will limit $\mathrm{Fe}(\mathrm{VI})$ 's potential to destroy tetrabromobisphenol-A entirely. Tetrabromobisphenol-A has been entirely removed in the existence of humic acid where an excess of $\mathrm{Fe}$ (VI) has been added. The results of the processes showed that TBBPA was degraded by $\beta$ fracturing, which resulted in de-brominated oxidised products with low molecular weight (Yang et al., 2014). Importantly, tetrabromobisphenol-A's oxidative $\mathrm{Fe}(\mathrm{VI})$ based transition has led tetrabromobisphenol-A to lose some hormone functions, including generally pro-estrogenic, valerate, and anti-androgenic (Yang et al., 2014).

The kinetic reactions between $\mathrm{Fe}(\mathrm{VI})$ and phenolic estrogens showed effective steroid elimination. The degradation of estrogen in fresh water, wastewater, and milk-based waste lagoons by $\mathrm{Fe}(\mathrm{VI})$ has shown this ( $\mathrm{Hu}$ et al., 2008; Lee et al., 2005; Remsberg et al., 2008). While this occurrence of organic manures in polluted water has impaired the 17 $\alpha$-ethinyl-estradiol (EE2) breakdown, the growing dose of $\mathrm{Fe}(\mathrm{VI})$ means that the waste water sample obtained the entire estrogen extracted ( $\mathrm{Hu}$ et al., 2008; Lee et al., 2005). The estrogenic content of 
$\alpha$-ethinyl-estradiol after $\mathrm{Fe}(\mathrm{VI})$ therapies has been analysed and disclosed that the original manufacturing products also have in situ antioxidant activities (Lee et al., 2008).

Nevertheless, $\mathrm{Fe}(\mathrm{VI})$ has been used to convert the initially generated products to eliminate the estrogenic activity of $\alpha$-ethinyl-estradiol by oxidation (Lee et al., 2008). The pharmaceutical pollutants including cimetidine, nalidixic acid, famotidine, caffine and tinidazole can effectively degrade at $\mathrm{pH} 8.0$ with the second order reaction rate. The rate constant of these pollutant ranges from 5.0 to 9.5 and conclude that the $\mathrm{k}_{\mathrm{app}}$ decrease with the increase in reaction $\mathrm{pH}$. The fluorescence surrogate accuracy was determined by field sample for the elimination of pharmaceutical pollutants. During Fe(VI) treatment, authors conclude that the fluorescence of the pollutant change as the pollutant degrade. Fe (VI) with three different exposure dose (100-213 $\mathrm{mgL}^{-1} \mathrm{~min}$ ) was deployed, the result conclude that carbamazepine, trimethoprim and diclofenac can be degraded with low dose of Fe(VI) (26-38.8 $\mathrm{mgL}^{-1}$ min) (Ni et al., 2020).

\subsection{Reductants and products obtained by $\mathrm{Fe}(V I)$}

In the study of $\mathrm{Fe}(\mathrm{VI})$ oxidation reactions, the interplay between $\mathrm{Fe}$ (VI) and the aqueous solution should be taken in account (Lee et al., 2014; Sharma, 2011). Initial Fe(VI)concentration, temperature, $\mathrm{pH}$, water components, and the composition of the oxides/hydrous iron oxide provide a significant effect on ferrate oxidation level.

$2 \mathrm{FeO}_{4}{ }^{2-}+5 \mathrm{H}_{2} \mathrm{O} \rightarrow 2 \mathrm{Fe}^{3+}+3 / 2 \mathrm{O}_{2}+10 \mathrm{OH}^{-}$

Eq. 14

Table 5 gives the main products of $\mathrm{Fe}(\mathrm{VI})$ reactions with various organic substrates (Carr, 2008; Delaude and Laszlo, 1996; Huang et al., 2001a; Huang et al., 2001b; Johnson et al., 2008; Kim et al., 1984; Lee and Gai, 1993; Norcross et al., 1997; Ohta et al., 2001; Rush et al., 1995). Hydrocarbons are manufactured from natural hydroxylated compounds and alcohols via aldehydes/ketones (Kim et al., 1984; Lee and Gai, 1993). Fe(VI) amine degradation varies, with respect to temperature and because of different nature of amine (Table 5). Formalamide and cyanate have been the primary components of methylamine degradation, and formic acid has been the ultimate result of dimethylamine and trimethylamine oxidation (Johnson et al., 2008). This indicates that methylamine decay by $\mathrm{Fe}(\mathrm{VI})$ reactions vary from dimethylamine and trimethylamine degradation by Fe(VI). Due to aniline accumulation by $\mathrm{Fe}(\mathrm{VI})$, two forms of oxidised products were produced. When $\mathrm{Fe}(\mathrm{VI})$ content was more significant than aniline, nitrobenzene was perhaps the most abundant element. Azobenzene was produced when the aniline intensity was greater than the $\mathrm{Fe}(\mathrm{VI})$ levels (Huang et al., 2001a; Johnson et al., 2008). In another study, the author

Table 5

Reaction intermediate products generated by ferrate degradation.

\begin{tabular}{|c|c|c|}
\hline Reductant & Products & Reference \\
\hline Hydrocarbons & $\begin{array}{l}\text { Hydroxylated } \\
\text { compounds }\end{array}$ & $\begin{array}{l}\text { (Delaude and Laszlo, 1996; } \\
\text { Kim et al., 1984) }\end{array}$ \\
\hline Alcohols & Aldehyde and ketone & $\begin{array}{l}\text { (Lee and Gai, 1993; Ohta } \\
\text { et al., 2001) }\end{array}$ \\
\hline $\begin{array}{l}\text { Amines } \\
\text { - Methylamine }\left(1^{\circ} \mathrm{C}\right) \\
\text { - Dimethylamine } \\
\left(2^{\circ} \mathrm{C}\right) \\
\text { - Trimethylamine } \\
\left(3^{\circ} \mathrm{C}\right)\end{array}$ & $\begin{array}{l}\text { Formamide, cyanate } \\
\text { Formic acid } \\
\text { Formic acid }\end{array}$ & Carr (2008) \\
\hline Aniline & $\begin{array}{l}\text { Nitrobenzene, } \\
\text { azobenzene }\end{array}$ & $\begin{array}{l}\text { (Huang et al., 2001a; } \\
\text { Johnson et al., 2008) }\end{array}$ \\
\hline Phenol & $\begin{array}{l}\text { p-benzoquinone and } \\
\text { biphenol }\end{array}$ & $\begin{array}{l}\text { (Huang et al., 2001a; Rush } \\
\text { et al., 1995) }\end{array}$ \\
\hline $\begin{array}{l}\text { Aliphatic sulfur } \\
\text { compounds }\end{array}$ & $\begin{array}{l}\text { Sulfenic, sulfinic, } \\
\text { sulfonic, sulphate }\end{array}$ & Sharma (2011) \\
\hline Thiols & Sulfonate, disulfide & $\begin{array}{l}\text { (Delaude and Laszlo, 1996; } \\
\text { Sharma, 2011) }\end{array}$ \\
\hline
\end{tabular}

revealed that the value of $k_{a p p}$ of organic amine is much higher than aliphatic amine. The formation products of aliphatic amine are revealed as in the reaction equation (Eqs. 15-17) (Carr, 2008; Sharma, 2013).

$$
\begin{array}{ll}
\mathrm{FeO}_{4}{ }^{2-}+\mathrm{CH}_{3} \mathrm{NH}_{2} \rightarrow \mathrm{Fe}(\mathrm{IV})+\mathrm{CH}_{2}=\mathrm{NH}+\mathrm{H}_{2} \mathrm{O} & \text { Eq. } 15 \\
\mathrm{FeO}_{4}{ }^{2-}+\mathrm{CH}_{2}=\mathrm{NH} \rightarrow \mathrm{Fe}(\mathrm{IV})+\mathrm{HCO}_{-}-\mathrm{NH}_{2} & \text { Eq. } 16 \\
\mathrm{FeO}_{4}{ }^{2-}+\mathrm{HCO}_{-} \mathrm{NH}_{2} \rightarrow \mathrm{Fe}(\mathrm{IV})+\mathrm{NCO}^{-}+\mathrm{H}_{2} \mathrm{O} & \text { Eq. } 17
\end{array}
$$

In a recent study, the degradation of pharmaceuticals, antibiotics and personal care products were oxidized by $\mathrm{Fe}(\mathrm{VI})$ and biochar. The result revealed the increase in degradation rate from 3 to 14 time and TOC removal was enhanced by $2.4-8$ times. The oxidant not only formed the intermediate but also cause detrimental effects to biochar structure (Tian et al., 2020). Two drugs, p-benzoquinone and biphenol, were obtained from phenol oxidation. Biphenol formation shows that during $\mathrm{Fe}(\mathrm{VI})$ phenol oxidation, a radical reaction has developed. The Fe(VI) can oxidize the aliphatic and aromatic sulfur compounds through an oxygen transfer mechanism (Huang et al., 2001a).

\subsection{Applications in wastewater treatment}

The Fe(VI) has a superior range of applicability which can be theoretically associated with wastewater cleaning, but if manufactured in large amounts, the cost can be significantly decrease. Author studied the onsite waste water treatment by $\mathrm{Fe}(\mathrm{VI})$, the onsite utilization and production of $\mathrm{Fe}(\mathrm{VI})$ constructed with $220 \mathrm{~mL}$ electro-chemical reactor, dosing pump liked with storage tank. The electrochemical reactor is explained in Fig. 6, where 2mnn thick anode and cathode with 3.6 $\mathrm{mAcm}^{-2}$ were used. In the result, $\mathrm{Fe}(\mathrm{VI})$ significantly degrade the total phosphorus (56\%) and total soluble solids (79\%) (Alsheyab et al., 2010; Jiang et al., 2016). Further improvements have been observed to increase the efficiency like cleaning of anode with phosphoric acid solution. In a study $\mathrm{Fe}(\mathrm{VI})$ with combination of cationic polymer was used to remediate dyeing waste water. The treated pilot scale plant raised the conductivity, calcium and hardness while significantly reduced the iron and magnesium (Ciabatti et al., 2010). In another study, Fe(VI) and ozone were applied simultaneously to conclude the pilot scale comparison of waste water. The result conclude that $\mathrm{Fe}(\mathrm{VI})$ and ozone can remove $80 \%$ and $60 \%$ of the aniline respectively. Total organic carbon was significantly lower than the targeted pollutant which reflect that the complete mineralization has not been achieved (Liu et al., 2011).

The conclusive aspects of $\mathrm{Fe}(\mathrm{VI})$ with wate water treatment are:

(a) Electrochemical produced $\mathrm{Fe}(\mathrm{VI})$ has more wide application as compare to wet oxidised method in waste water treatment

(b) The cleaning of anode surface and composition of analyte can improve the efficacy.

(c) The composition of liquid Fe(VI) with highly alkaline and soluble/residual content are another problematic concern.

(d) It produces a $\mathrm{Fe}(\mathrm{OH})_{3}$ gel that drops and contains other particles.

(e) The reaction condition $(\mathrm{pH}$, anions, cations, chemical structure and concentration of the contaminant greatly influence the degradation trend).

\section{Limitations and perspective}

There are number of future prospective which can be induced in oxidative degradation includes:

(1) Stability concern: The stability concern is the main and major goal in $\mathrm{Fe}(\mathrm{VI})$ oxidation. The self-decay of $\mathrm{Fe}(\mathrm{VI})$ may lead to poor oxidation. $\mathrm{Fe}(\mathrm{VI})$ is very unstable at acidic $\mathrm{pH}$ and show maximum reactivity at basic $\mathrm{pH}$. The most of the reaction shows second-order reaction kinetics. But their decay mechanism is 


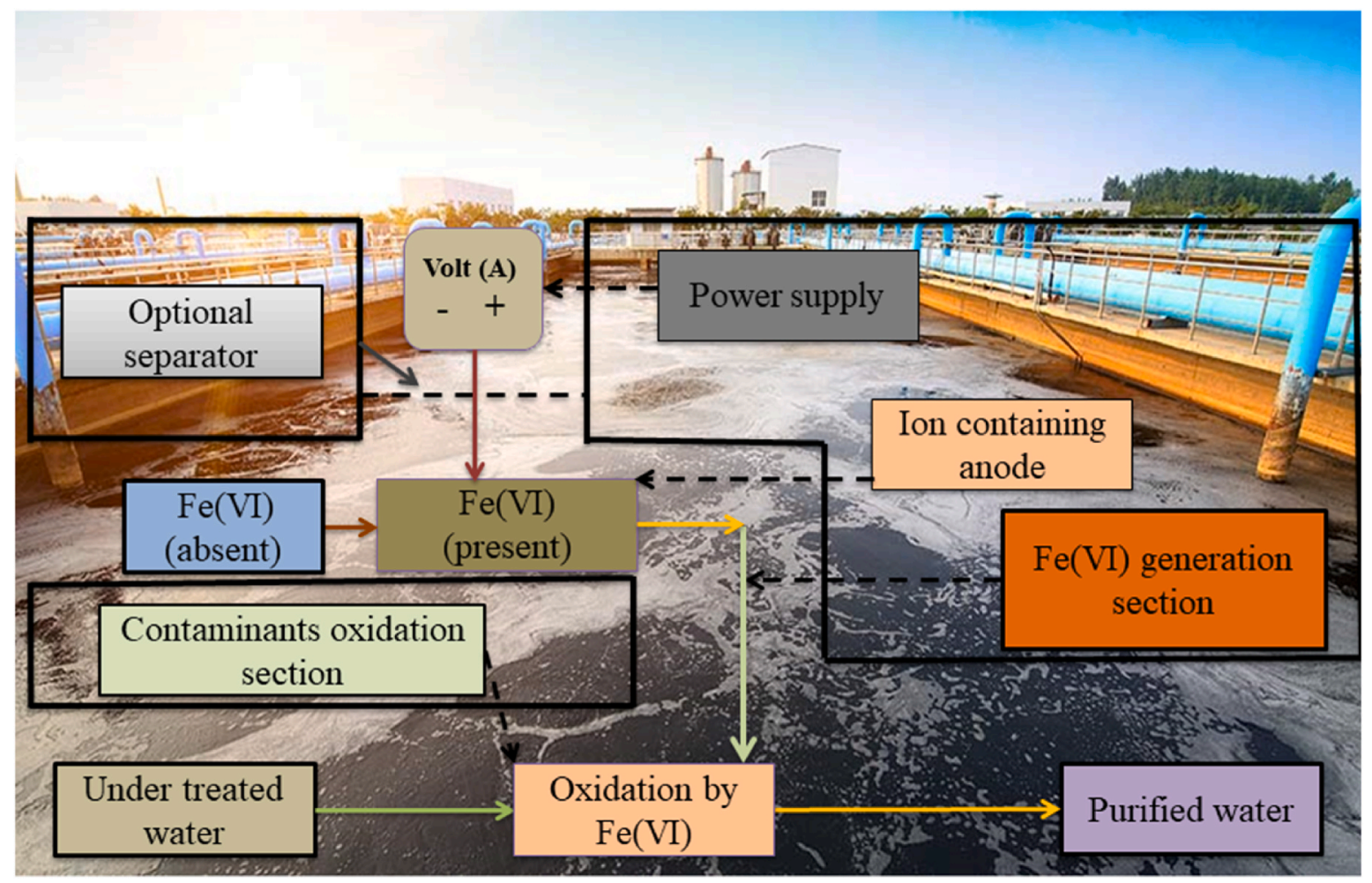

Fig. 6. Complete pathway of wastewater treatment by ferrate.

confused and controversial under different reaction conditions. A new method can be introduced to approach maximum degradation, like frozen $\mathrm{Fe}(\mathrm{VI})$ can be an innovative method, as basically we need a slow release of $\mathrm{Fe}(\mathrm{VI})$ in the reaction system. Because in most of the reaction, up to $70 \%$ degradation takes place in early few minutes. So frozen $\mathrm{Fe}(\mathrm{VI})$ can be an effective method for the slow release of $\mathrm{Fe}(\mathrm{VI})$.

(2) $\mathrm{Fe}(\mathrm{III})$ and $\mathrm{Fe}(\mathrm{IV})$ generation: As with comprehensive support of this article, the redox potential of $\mathrm{Fe}(\mathrm{III})$ is more valuable than $\mathrm{Fe}$ (VI). Even the generation of Fe(IV) and their reaction mechanism still need to be studied. So, there should be more studies focusing on the generation of Fe(III) and Fe(IV).

(3) Nanopores entrapment and nanopore capsules: A number of studies have incorporated in homogenous reaction, while there is significant potential in the heterogeneous reaction system. Nanopores, with the help of zeolite and silicon dioxide, can be generated and apply with $\mathrm{Fe}(\mathrm{VI})$, as they have more absorbance capacity. In addition, nano pore which has a smaller pore than $\mathrm{Fe}$ (VI), can be used to form capsule shell, once capsule formed it will not allow escaping/self-decay. When the capsule needs to dissociate, some external signal (It may UV, temperature) may require, $\mathrm{Fe}(\mathrm{VI})$ will be able to degrade the pollutant. Besides, we may also intrude some other methods like UV method to reach out the mechanistic approach.

(4) Activation and synergetic effects: Fe(VI) activation by different agents, including photocatalyst, can be an effective approach to overcome the time-consuming process (like encapsulated $\mathrm{Fe}(\mathrm{VI})$ ). The generation of an electron during photocatalytic activity may enhance the degradation efficiency, and meanwhile, synergetic effects can be generated.

\section{Conclusion}

$\mathrm{Fe}(\mathrm{VI})$ is a substance that oxidizes the hydrocarbon, alcoholic and phenolic derivatives, nitrogen compounds. This study offers previous comprehensive studies and a comparative comparison of $\mathrm{Fe}(\mathrm{VI})$ alternative treatment strategies for environmental pollutants. At the beginning, we elucidated the characteristics of different advanced oxidation processes. Although research on these deterioration methods has shown a steady global rise over the last 20 years, these studies comprise a number of limitations, which are briefly addressed in this review. The Fe (VI) reaction mechanism addresses the generation of one and two electrons which mediate the degradation intermediate. The generation of $\mathrm{Fe}(\mathrm{III})$ and their redox potential are more concerning in degradation than $\mathrm{Fe}(\mathrm{V})$ and $\mathrm{Fe}(\mathrm{VI})$.

The recent advancement in $\mathrm{Fe}(\mathrm{VI})$ provides the $\mathrm{Fe}(\mathrm{VI})$ activation by different activation agent, and these studies offer the more comprehensive details as compared to $\mathrm{Fe}(\mathrm{VI})$ alone. These are summarized as (1) $\mathrm{Fe}(\mathrm{VI})$ was able to activate $\mathrm{C}-\mathrm{H}$ hydrocarbon bond by the related heterogeneous catalysts and to turn benzyl alcohol into benzaldehyde by stoichiometry without over-oxidation into benzoic acid. (2) The photocatalytic intermediates often establish environmental toxicity to different species. The scientific establishment should pay particular attention to these limits. (3) Petrochemical waste is toxic and, even at very low concentrations, has numerous harmful effects on human health and the environment. It takes hour to establish a practical methodology for the degradation of this organic pollutant, economically and sustainably. It is important to ensure technical advances in implementing the various biological and photocatalytic systems in petrochemical waste management. (4) Advances have been made on the kinetics of $\mathrm{Fe}$ (VI) oxidation of pharmaceuticals, but there is a lack of knowledge on stoichiometry and reaction products including reaction intermediates, self and cross coupling products. The synergetic effects can be achieved by implementing photoactivation reagent with $\mathrm{Fe}(\mathrm{VI})$. This approach can provide real-life information about treatment processes. Finally, research on organic molecule synthesis and transformation will begin to find viable new applications in greener processing and therapy for earthabundant iron-based products. 


\section{Author's statement}

Afzal Ahmed Dar and Chuanyi Wang conceptualized the initial draft, Eric Lichtfouse, and Usman reviewed and highlighted the gaps, Bao, Zhu and Qin helped in data collection, and moderation. All authors reviewed, edited, and agreed on the final version of the manuscript. In addition, authors declare no financial and competing interest.

\section{Authors' contributions}

Afzal Ahmed Dar and Chuanyi Wang conceptualized the initial draft, Eric Lichtfouse, and Usman reviewed and highlighted the gaps, Bao, Zhu and Qin helped in data collection, and moderation. All authors reviewed, edited, and agreed on the final version of the manuscript.

\section{Declaration of competing interest}

The authors declare that they have no known competing financial interests or personal relationships that could have appeared to influence the work reported in this paper.

\section{Acknowledgement}

We would like to acknowledge all contributors for their efforts. The authors would like to acknowledge the China postdoctoral foundation for regional support research grant (2021 M693857) and National Natural Science Foundation of China (21902095).

\section{References}

Acosta-Rangel, A., et al., 2020. Oxidation of sulfonamides by ferrate (VI): reaction kinetics, transformation byproducts and toxicity assesment. J. Environ. Manag. 255, 109927.

Akbari, M.S.A., et al., 2020. oxygen-evolution reaction by nickel/nickel oxide interface in the presence of ferrate (Vi). Sci. Rep. 10, 1-11.

Ali, M., et al., 2020. Microwave-assisted ultrafast in-situ growth of N-doped carbon quantum dots on multiwalled carbon nanotubes as an efficient electrocatalyst for photovoltaics. J. Colloid Interface Sci. 586, 349-361.

Alsheyab, M., et al., 2010. Engineering aspects of electrochemical generation of ferrate: a step towards its full scale application for water and wastewater treatment. Water, Air, Soil Pollut. 210, 203-210.

Anquandah, G.A., Sharma, V.K., 2009. Oxidation of octylphenol by ferrate (VI). Journal of Environmental Science and Health, Part A. 44, 62-66.

Anquandah, G.A., et al., 2011. Oxidation of trimethoprim by ferrate (VI): kinetics, products, and antibacterial activity. Environ. Sci. Technol. 45, 10575-10581.

Aslani, H., et al., 2017. Haloacetic acids degradation by an efficient Ferrate/UV process: byproduct analysis, kinetic study, and application of response surface methodology for modeling and optimization. J. Environ. Manag. 203, 218-228.

Azbar, N., et al., 2005. Application of Advanced Oxidation Processes (AOPs) to Wastewater Treatment. Case Studies: Decolourization of Textile Effluents, Detoxification of Olive Mill Effluent, Treatment of Domestic Wastewater, AR Burk. Nova Science Publishers, Water Pollution: New Research, New York, pp. 99-118.

Banjac, Z., et al., 2015. Emission factor estimation of ca. 160 emerging organic microcontaminants by inverse modeling in a Mediterranean river basin (Llobregat, NE Spain). Sci. Total Environ. 520, 241-252.

Barıșçı, S., Ulu, F., Sillanpää, M., Dimoglo, A., 2015. Evaluation of flurbiprofen remova from aqueous solution by electrosynthesized ferrate (VI) ion and electrocoagulation process. Chem. Eng. J. 262, 1218-1225.

Bhavya, G., et al., 2021. Remediation of emerging environmental pollutants: a review based on advances in the uses of eco-friendly biofabricated nanomaterials. Chemosphere Jul (275). https://doi.org/10.1016/j.chemosphere.2021.129975, 129975.

Cai, J., et al., 2018. Degradation and mechanism of 2, 4-dichlorophenoxyacetic acid (2 4-D) by thermally activated persulfate oxidation. Chemosphere 212, 784-793.

Carr, J.D., 2008. Kinetics and Product Identification of Oxidation by Ferrate (VI) of Water and Aqueous Nitrogen Containing Solutes. ACS Publications.

Casbeer, E.M., et al., 2013. Kinetics and mechanism of oxidation of tryptophan by ferrate (VI). Environ. Sci. Technol. 47, 4572-4580.

Chen, B.-Y., et al., 2019. Chitosan encapsulation of ferrate VI for controlled release to water: mechanistic insights and degradation of organic contaminant. Sci. Rep. 9, $1-11$.

Chen, J., et al., 2018. Ferrate (VI) oxidation of polychlorinated diphenyl sulfides: kinetics, degradation, and oxidized products. Water Res. 143, 1-9.

Chen, W., et al., 2016. Effective mineralization of Diclofenac by catalytic ozonation using Fe-MCM-41 catalyst. Chem. Eng. J. 304, 594-601.

Chen, Y., et al., 2015. UV/ferrate (VI) oxidation of profenofos: efficiency and mechanism. Desalination and Water Treatment 55, 506-513.
Chiu, J.M., et al., 2016. A novel approach for estimating the removal efficiencies of endocrine disrupting chemicals and heavy metals in wastewater treatment processes. Mar. Pollut. Bull. 112, 53-57.

Chuang, Y.-H., et al., 2019. Pilot-scale comparison of microfiltration/reverse osmosis and ozone/biological activated carbon with UV/hydrogen peroxide or UV/free chlorine AOP treatment for controlling disinfection byproducts during wastewater reuse. Water Res. 152, 215-225.

Ciabatti, I., et al., 2010. Treatment and reuse of dyeing effluents by potassium ferrate. Desalination 250, 222-228.

Cizmas, L., et al., 2015. Pharmaceuticals and personal care products in waters: occurrence, toxicity, and risk. Environ. Chem. Lett. 13, 381-394.

Dar, A.A., et al., 2019. Ozonation of pentabromophenol in aqueous basic medium: kinetics, pathways, mechanism, dimerization and toxicity assessment. Chemosphere 220, 546-555.

Delaude, L., Laszlo, P., 1996. A novel oxidizing reagent based on potassium ferrate (VI). J. Org. Chem. 61, 6360-6370.

Diak, J., Örmeci, B., 2016. Individual and combined effects of freeze-thaw and ferrate (VI) oxidation for the treatment and dewatering of wastewater sludges. Water, Air, Soil Pollut. 227, 331.

Elnakar, H., Buchanan, I., 2020. Treatment of bypass wastewater using novel integrated potassium ferrate (VI) and iron electrocoagulation system. J. Environ. Eng. 146, 04020075 .

Eng, Y.Y., et al., 2006. Ferrate (VI): green chemistry oxidant for degradation of cationic surfactant. Chemosphere 63, 1785-1790.

Evgenidou, E.N., et al., 2015. Occurrence and removal of transformation products of PPCPs and illicit drugs in wastewaters: a review. Sci. Total Environ. 505, 905-926.

Feng, M., et al., 2018. Accelerated oxidation of organic contaminants by ferrate (VI): the overlooked role of reducing additives. Environ. Sci. Technol. 52, 11319-11327.

Feng, M., Sharma, V.K., 2018. Enhanced oxidation of antibiotics by ferrate (VI)-sulfur (IV) system: elucidating multi-oxidant mechanism. Chem. Eng. J. 341, 137-145.

Feng, M., et al., 2016. Degradation of fluoroquinolone antibiotics by ferrate (VI): effects of water constituents and oxidized products. Water Res. 103, 48-57.

Filip, J., et al., 2011. Mechanisms and efficiency of the simultaneous removal of metals and cyanides by using ferrate (VI): crucial roles of nanocrystalline iron (III) oxyhydroxides and metal carbonates. Chemistry-A European Journal 17, 10097-10105.

Fuerhacker, M., et al., 2001. Adsorption isotherms of $17 \beta$-estradiol on granular activated carbon (GAC). Chemosphere 44, 1573-1579.

Gago-Ferrero, P., et al., 2017. Impact of on-site, small and large scale wastewater treatment facilities on levels and fate of pharmaceuticals, personal care products, artificial sweeteners, pesticides, and perfluoroalkyl substances in recipient waters Sci. Total Environ. 601, 1289-1297.

Gan, W., et al., 2015. Investigation of disinfection byproducts formation in ferrate (VI) pre-oxidation of NOM and its model compounds followed by chlorination. J. Hazard Mater. 292, 197-204.

Gao, Y., et al., 2020. Quantitative evaluation of relative contribution of high-valent iron species and sulfate radical in Fe (VI) enhanced oxidation processes via sulfur reducing agents activation. Chem. Eng. J. 387, 124077.

Geetha, N., et al., 2021. Insights into nanomycoremediation: secretomics and mycogenic biopolymer nanocomposites for heavy metal detoxification. J. Hazard Mater. 409, 124541.

Ghosh, M., et al., 2019. Rapid removal of acesulfame potassium by acid-activated ferrate (VI) under mild alkaline conditions. Chemosphere 230, 416-423.

Gilbert, M.B., et al., 1976. Analytical notes - an investigation of the applicability of ferrate ion for disinfection. J. Am. Water Works Assoc. 68, 495-497.

Grote, B., 2012. Application of advanced oxidation processes (AOP) in water treatment. In: 37th Annual Old Water Industry Operations Workshop Parklands. Gold Coast, pp. 17-23.

Han, Q., et al., 2013. Effects of coexisting anions on decolorization of azo dye X-3B by ferrate (VI) and a comparative study between ferrate (VI) and potassium permanganate. Separ. Purif. Technol. 108, 74-82.

Han, Q., et al., 2015. Degradation of bisphenol A by ferrate (VI) oxidation: kinetics, products and toxicity assessment. Chem. Eng. J. 262, 34-40.

Haneef, T., et al., 2020. Study of Ferrate (VI) oxidation for COD removal from wastewater. EES (Ecotoxicol. Environ. Saf.) 442, 012007.

$\mathrm{Hu}$, J., et al., 2008. Oxidation of hormone estrogens in water using potassium ferrate (VI). Adv. Asian Environ. Eng. 17, 89-94.

Hu, L., et al., 2009. Oxidation of carbamazepine by Mn (VII) and Fe (VI): reaction kinetics and mechanism. Environ. Sci. Technol. 43, 509-515.

$\mathrm{Hu}$, J., et al., 2020. Using a strong chemical oxidant, potassium ferrate (K2FeO4), in waste activated sludge treatment: a review. Environ. Res. Sep (188) https://doi.org/ 10.1016/j.envres.2020.109764, 109764.

Hu, L., Xia, Z., 2018. Application of ozone micro-nano-bubbles to groundwater remediation. J. Hazard Mater. 342, 446-453.

Huang, H., et al., 2001a. Ferrate (VI) oxidation of aqueous phenol: kinetics and mechanism. J. Phys. Chem. 105, 3536-3541.

Huang, H., et al., 2001b. Ferrate (VI) oxidation of aniline. J. Chem. Soc. Dalton Trans. 1301-1305.

Huber, M.M., et al., 2005a. Oxidation of pharmaceuticals during ozonation of municipal wastewater effluents: a pilot study. Environ. Sci. Technol. 39, 4290-4299.

Huber, M.M., et al., 2005b. Oxidation of pharmaceuticals during water treatment with chlorine dioxide. Water Res. 39, 3607-3617.

Hübner, U., Jekel, M., 2013. Tertiary treatment of Berlin WWTP effluents with ferrate (Fe (VI)). Water Sci. Technol. 68, 1665-1671. 
Huo, C., et al., 2020. Groundwater contamination with the threat of COVID-19: insights into CSR theory of Carroll's pyramid. J. King Saud Univ. Sci. 33 (2), 101295 https:/ doi.org/10.1016/j.jksus.2020.101295. March 2021.

Jepson, P.D., Law, R.J., 2016. MARINE ENVIRONMENT. Persistent pollutants, persistent threats. Science (New York, NY) 352, 1388-1389.

Jiang, H., et al., 2003. Holistic twig joins on indexed XML documents. In: Proceedings 2003 VLDB Conference. Elsevier, pp. 273-284.

Jiang, J.-Q., Lloyd, B., 2002. Progress in the development and use of ferrate (VI) salt as an oxidant and coagulant for water and wastewater treatment. Water Res. 36, 1397-1408.

Jiang, J.-Q., et al., 2006. The application of potassium ferrate for sewage treatment. J. Environ. Manag. 79, 215-220.

Jiang, J.-Q., et al., 2007. The role of potassium ferrate (VI) in the inactivation of Escherichia coli and in the reduction of COD for water remediation. Desalination 210, 266-273.

Jiang, J.-Q., et al., 2013. Occurrence, transportation, monitoring and treatment of emerging micro-pollutants in waste water-a review from global views. Microchem. J. 110, 292-300.

Jiang, J.Q., 2014. Advances in the development and application of ferrate (VI) for water and wastewater treatment. J. Appl. Chem. Biotechnol. 89, 165-177.

Jiang, W., et al., 2014. Oxidation of microcystin-LR by ferrate (VI): kinetics, degradation pathways, and toxicity assessments. Environ. Sci. Technol. 48, 12164-12172.

Jiang, Y., et al., 2016. Impacts of ferrate oxidation on natural organic matter and disinfection byproduct precursors. Water Res. 96, 114-125.

Johnson, M.D., et al., 2008. Ferrate (VI) Oxidation of Nitrogenous Compounds. ACS Publications.

Kalliora, C., et al., 2018. Association of pesticide exposure with human congenital abnormalities. Toxicol. Appl. Pharmacol. 346, 58-75.

Karlesa, A., et al., 2014. Ferrate (VI) oxidation of $\beta$-lactam antibiotics: reaction kinetics, antibacterial activity changes, and transformation products. Environ. Sci. Technol, 48, 10380-10389.

Khetan, S.K., Collins, T.J., 2007. Human pharmaceuticals in the aquatic environment: a challenge to green chemistry. Chem. Rev. 107, 2319-2364.

Kim, C., et al., 2015. Ferrate promoted oxidative cleavage of sulfonamides: kinetics and product formation under acidic conditions. Chem. Eng. J. 279, 307-316.

Kim, K.S., et al., 1984. Selective Oxidation of Allylic and Benzylic Alcohols Using Potassium Ferrate under Phase-Transfer Catalysis Condition, pp. 866-868. Synthesis (Stuttgart).

Klatte, S., et al., 2017. Pharmaceuticals in the environment-a short review on options to minimize the exposure of humans, animals and ecosystems. Sustainable Chemistry and Pharmacy 5, 61-66.

Krasner, S.W., et al., 2013. Formation, precursors, control, and occurrence of nitrosamines in drinking water: a review. Water Res. 47, 4433-4450.

Lee, D.G., Gai, H., 1993. Kinetics and mechanism of the oxidation of alcohols by ferrate ion. Can. J. Chem. 71, 1394-1400.

Lee, Y., et al., 2004. Chemistry of ferrate (Fe (VI)) in aqueous solution and its applications as a green chemical. JOURNAL OF INDUSTRIAL AND ENGINEERING CHEMISTRY-SEOUL- 10, 161-171.

Lee, Y., et al., 2008. Efficient removal of estrogenic activity during oxidative treatment of waters containing steroid estrogens. Environ. Sci. Technol. 42, 6333-6339.

Lee, Y., et al., 2014. Reaction of ferrate (VI) with ABTS and self-decay of ferrate (VI): kinetics and mechanisms. Environ. Sci. Technol. 48, 5154-5162.

Lee, Y., Von Gunten, U., 2010. Oxidative transformation of micropollutants during municipal wastewater treatment: comparison of kinetic aspects of selective (chlorine, chlorine dioxide, ferrateVI, and ozone) and non-selective oxidants (hydroxyl radical). Water Res. 44, 555-566.

Lee, Y., et al., 2005. Kinetics of the oxidation of phenols and phenolic endocrine disruptors during water treatment with ferrate (Fe (VI)). Environ. Sci. Technol. 39, 8978-8984.

Lee, Y., et al., 2009. Ferrate (Fe (VI)) application for municipal wastewater treatment: a novel process for simultaneous micropollutant oxidation and phosphate removal. Environ. Sci. Technol. 43, 3831-3838.

Li, C., et al., 2008. The aqueous degradation of bisphenol A and steroid estrogens by ferrate. Water Res. 42, 109-120.

Li, X.D., Schwartz, F.W., 2005. Using Phosphate to Control the Mn Oxide Precipitation during in Situ Chemical Oxidation of Chlorinated Ethylenes by Permanganate. ACS Publications.

Licht, S., et al., 2008. Electrochemical Fe (VI) Water Purification and Remediation. ACS Publications.

Lin, C.-E., et al., 1997. Migration behavior and separation of sulfonamides in capillary zone electrophoresis III. Citrate buffer as a background electrolyte. J. Chromatogr. A 768, 105-112.

Liu, X., et al., 2011. Retention-oxidation-adsorption process for emergent treatment of organic liquid spills. J. Hazard Mater. 195, 162-169.

Liu, Y., et al., 2016. Improvement of settleability and dewaterability of sludge by newly prepared alkaline ferrate solution. Chem. Eng. J. 287, 11-18.

Liu, Y., et al., 2018. Enhanced degradation and mineralization of 4-chloro-3-methyl phenol by Zn-CNTs/O3 system. Chemosphere 191, 54-63.

Luo, C., et al., 2019. Oxidation of pharmaceuticals by ferrate (VI) in hydrolyzed urine: effects of major inorganic constituents. Environ. Sci. Technol. 53, 5272-5281.

Luo, S., et al., 2017. Mechanistic insight into reactivity of sulfate radical with aromatic contaminants through single-electron transfer pathway. Chem. Eng. J. 327, 1056-1065.

Luo, S., et al., 2018. UV direct photolysis of sulfamethoxazole and ibuprofen: an experimental and modelling study. J. Hazard Mater. 343, 132-139.
Mackul'ak, T., et al., 2013. Treatment of industrial wastewater with high content of polyethylene glycols by Fenton-like reaction system (Fe0/H2O2/H2SO4). Desalination and Water Treatment 51, 4489-4496.

Manoli, K., et al., 2017a. Silica gel-enhanced oxidation of caffeine by ferrate (VI). Chem. Eng. J. 330, 987-994.

Manoli, K., et al., 2017b. Enhanced oxidative transformation of organic contaminants by activation of ferrate (VI): possible involvement of FeV/FeIV species. Chem. Eng. J. 307, 513-517.

Matafonova, G., Batoev, V., 2018. Recent advances in application of UV light-emitting diodes for degrading organic pollutants in water through advanced oxidation processes: a review. Water Res. 132, 177-189.

Mboula, V.M., et al., 2015. Photocatalytic degradation of estradiol under simulated solar light and assessment of estrogenic activity. Appl. Catal. B Environ. 162, 437-444.

Michael, I., et al., 2013. Urban wastewater treatment plants as hotspots for the release of antibiotics in the environment: a review. Water Res. 47, 957-995.

Ni, J.S., et al., 2020. Planar AIEgens with enhanced solid-state luminescence and ROS generation for multidrug-resistant bacteria treatment. Angew. Chem. Int. Ed. 59, 10179-10185.

Nie, J., et al., 2020. Development of fluorescence surrogates to predict the ferrate (VI) oxidation of pharmaceuticals in wastewater effluents. Water Research, p. 116256.

Noorhasan, N., et al., 2010. Ferrate (VI) oxidation of glycine and glycylglycine: kinetics and products. Water Res. 44, 927-935.

Norcross, B.E., et al., 1997. The oxidation of secondary alcohols by potassium tetraoxoferrate (VI). Can. J. Chem. 75, 129-139.

Ohta, T., et al., 2001. A theoretical study of alcohol oxidation by ferrate. J. Org. Chem. $66,4122-4131$.

Paidi, M.K., et al., 2021. Mitigation of organophosphorus insecticides from environment: residual detoxification by bioweapon catalytic scavengers. Environ. Res. 111368.

Pan, B., et al., 2020a. Enhanced ferrate (VI) oxidation of micropollutants in water by carbonaceous materials: elucidating surface functionality. Chem. Eng. J. 125607.

Pan, B., et al., 2019. Ultrathin Co0. 85Se nanosheet cocatalyst for visible-light CO2 photoreduction. Catal. Today 335, 208-213.

Pan, B., et al., 2020b. Oxygen-doping of ZnIn2S4 nanosheets towards boosted photocatalytic CO2 reduction. Journal of Energy Chemistry 57, 1-9. https://doi.org/ 10.1016/j.jechem.2020.08.024. June 2021.

Picó, Y., Barceló, D., 2015. Transformation products of emerging contaminants in the environment and high-resolution mass spectrometry: a new horizon. Anal. Bioanal. Chem. 407, 6257-6273.

Postigo, C., Richardson, S.D., 2014. Transformation of pharmaceuticals during oxidation/disinfection processes in drinking water treatment. J. Hazard Mater. 279, 461-475.

Premnath, N., et al., 2021. A crucial review on polycyclic aromatic HydrocarbonsEnvironmental occurrence and strategies for microbial degradation. Chemosphere 130608.

Prucek, R., et al., 2013. Ferrate (VI)-induced arsenite and arsenate removal by in situ structural incorporation into magnetic iron (III) oxide nanoparticles. Environ. Sci. Technol. 47, 3283-3292.

Qiang, Z., Adams, C., 2004. Potentiometric determination of acid dissociation constants (pKa) for human and veterinary antibiotics. Water Res. 38, 2874-2890.

Remsberg, J.R., et al., 2008. Removal of Estrogenic Compounds in Dairy Waste Lagoons by Ferrate (VI). ACS Publications.

Rivera-Utrilla, J., et al., 2009. Removal of nitroimidazole antibiotics from aqueous solution by adsorption/bioadsorption on activated carbon. J. Hazard Mater. 170, 298-305.

Ross, D.L., Riley, C.M., 1990. Aqueous solubilities of some variously substituted quinolone antimicrobials. Int. J. Pharm. 63, 237-250.

Roth, B., Strelitz, J.Z., 1969. Protonation of 2, 4-diaminopyrimidines. I. Dissociation constants and substituent effects. J. Org. Chem. 34, 821-836.

Rush, J., et al., 1995. The oxidation of phenol by ferrate (VI) andferrate (V). A pulse radiolysis and stopped-flow study. Free Radic. Res. 22, 349-360.

Satapute, P., et al., 2019. Physiological adaptation and spectral annotation of Arsenic and Cadmium heavy metal-resistant and susceptible strain Pseudomonas taiwanensis. Environ. Pollut. 251, 555-563.

Sharma, P., 2004. An overview of the field of family business studies: current status and directions for the future. Fam. Bus. Rev. 17, 1-36.

Sharma, V.K., 2002. Potassium ferrate (VI): an environmentally friendly oxidant. Adv. Environ. Res. 6, 143-156.

Sharma, V.K., 2011. Oxidation of inorganic contaminants by ferrates (VI, V, and IV)kinetics and mechanisms: a review. J. Environ. Manag. 92, 1051-1073.

Sharma, V.K., 2012. Kinetics and mechanism of formation and destruction of Nnitrosodimethylamine in water-A review. Separ. Purif. Technol. 88, 1-10.

Sharma, V.K., 2013. Ferrate (VI) and ferrate (V) oxidation of organic compounds: kinetics and mechanism. Coord. Chem. Rev. 257, 495-510.

Sharma, V.K., et al., 2009. Nonylphenol, octylphenol, and bisphenol-A in the aquatic environment: a review on occurrence, fate, and treatment. Journal of Environmental Science and Health Part A 44, 423-442.

Sharma, V.K., et al., 2008. Ferrate (VI) oxidation of endocrine disruptors and antimicrobials in water. J. Water Supply Res. Technol. - Aqua 57, 419-426.

Sharma, V.K., et al., 2013. Oxidation of $\beta$-lactam antibiotics by ferrate (VI). Chem. Eng. J. $221,446-451$.

Sharma, V.K., et al., 2011. Mechanisms of oxidation of organosulfur compounds by ferrate (VI). Chemosphere 82, 1083-1089.

Sharma, V.K., Mishra, S.K., 2006. Ferrate (VI) oxidation of ibuprofen: a kinetic study. Environ. Chem. Lett. 3, 182-185.

Sharma, V.K., et al., 2014a. Oxidation of artificial sweetener sucralose by advanced oxidation processes: a review. Environ. Sci. Pollut. Control Ser. 21, 8525-8533. 
Sharma, V.K., et al., 2014b. Formation and toxicity of brominated disinfection byproducts during chlorination and chloramination of water: a review. Journal of Environmental Science and Health, Part B. 49, 212-228.

Sharma, V.K., et al., 2015. Ferrates: greener oxidants with multimodal action in water treatment technologies. Acc. Chem. Res. 48, 182-191.

Shi, J., et al., 2015. Oxidative degradation of decabromodiphenyl ether (BDE 209) by potassium permanganate: reaction pathways, kinetics, and mechanisms assisted by density functional theory calculations. Environ. Sci. Technol. 49, 4209-4217.

Shin, J., et al., 2018. Reactions of ferrate (VI) with iodide and hypoiodous acid: kinetics, pathways, and implications for the fate of iodine during water treatment. Environ. Sci. Technol. 52, 7458-7467.

Sun, M., et al., 2019. Degradation of dye in wastewater by Homogeneous Fe (VI)/ NaHSO3 system. Chemosphere 228, 595-601.

Talaiekhozani, A., et al., 2016. Formaldehyde removal from wastewater and air by using UV, ferrate (VI) and UV/ferrate (VI). J. Environ. Manag. 184, 204-209.

Tian, S.-Q., et al., 2020. Degradation of organic pollutants by ferrate/biochar: enhanced formation of strong intermediate oxidative iron species. Water Res. 183, 116054.

Usman, M., Ho, Y.-S., 2020. A bibliometric study of the Fenton oxidation for soil and water remediation. J. Environ. Manag. 270, 110886.

Wang, H.-L., et al., 2009. Preparation and application of sustained release microcapsules of potassium ferrate (VI) for dinitro butyl phenol (DNBP) wastewater treatment. J. Hazard Mater. 169, 448-453.

Wang, J.L., Xu, L.J., 2012. Advanced oxidation processes for wastewater treatment: formation of hydroxyl radical and application. Crit. Rev. Environ. Sci. Technol. 42, 251-325.

Wang, Y., Hu, A., 2014. Carbon quantum dots: synthesis, properties and applications. J. Mater. Chem. C 2, 6921-6939.

Wilde, M.L., et al., 2013. Oxidation-coagulation of $\beta$-blockers by K2FeVIO4 in hospital wastewater: assessment of degradation products and biodegradability. Sci. Total Environ. 452, 137-147.

Wu, C., et al., 2020a. A review of the characteristics of fenton and ozonation systems in landfill leachate treatment. Sci. Total Environ. 143131.

Wu, S., et al., 2018. Performances and mechanisms of efficient degradation of atrazine using peroxymonosulfate and ferrate as oxidants. Chem. Eng. J. 353, 533-541.

Wu, S., et al., 2020b. Insights into mechanisms of UV/ferrate oxidation for degradation of phenolic pollutants: role of superoxide radicals. Chemosphere 244, 125490.

Xiao, R., et al., 2017. Mechanistic insight into degradation of endocrine disrupting chemical by hydroxyl radical: an experimental and theoretical approach. Environ. Pollut. 231, 1446-1452.
Xiao, R., et al., 2015. Quantitative structure-activity relationship (QSAR) for the oxidation of trace organic contaminants by sulfate radical. Environ. Sci. Technol. 49, 13394-13402.

Xu, L., Fu, F., 2020. Se (IV) oxidation by ferrate (VI) and subsequent in-situ removal of selenium species with the reduction products of ferrate (VI): performance and mechanism. Journal of Environmental Science and Health, Part A. 55, 528-536.

Yang, B., et al., 2014. Ferrate (VI) oxidation of tetrabromobisphenol A in comparison with bisphenol A. Water Res. 62, 211-219.

Yang, B., et al., 2012. Removal of selected endocrine disrupting chemicals (EDCs) and pharmaceuticals and personal care products (PPCPs) during ferrate (VI) treatment of secondary wastewater effluents. Water Res. 46, 2194-2204.

Yang, T., et al., 2020. Ferrate oxidation of bisphenol $\mathrm{F}$ and removal of oxidation products with ferrate resulted particles. Chem. Eng. J. 383, 123167.

Yang, Z., et al., 2017. Comparison of the reactivity of ibuprofen with sulfate and hydroxyl radicals: an experimental and theoretical study. Sci. Total Environ. 590, 751-760.

Yang, B., Ying, G.G., 2013. Oxidation of benzophenone-3 during water treatment with ferrate (VI). Water Res. 47 (7), 2458-2466.

Ye, T., et al., 2017. Chemical structure-based predictive model for the oxidation of trace organic contaminants by sulfate radical. Water Res. 116, 106-115.

Yonar, T., 2011. Decolorisation of textile dyeing effluents using advanced oxidation processes. In: Advances in Treating Textile Effluent. InTechOpen, Rijeka, pp. 1-26.

Zhang, W., et al., 2016. Variations in distribution and composition of extracellular polymeric substances (EPS) of biological sludge under potassium ferrate conditioning: effects of $\mathrm{pH}$ and ferrate dosage. Biochem. Eng. J. 106, 37-47.

Zheng, L., et al., 2020. Emergency water treatment with combined ferrate (vi) and ferric salts for disasters and disease outbreaks. Environ. Sci.: Water Res. Technol. 6 , 2816-2831. https://doi.org/10.1039/D0EW00483A.

Zhou, Z., Jiang, J.-Q., 2015a. Reaction kinetics and oxidation products formation in the degradation of ciprofloxacin and ibuprofen by ferrate (VI). Chemosphere 119, S95-S100.

Zhou, Z., Jiang, J.-Q., 2015b. Treatment of selected pharmaceuticals by ferrate (VI): performance, kinetic studies and identification of oxidation products. J. Pharmaceut. Biomed. Anal. 106, 37-45.

Zhu, H., et al., 2015. QSAR models for degradation of organic pollutants in ozonation process under acidic condition. Chemosphere 119, 65-71.

Zhu, X., et al., 2020. Accelerating effects of biochar for pyrite-catalyzed Fenton-like oxidation of herbicide 2, 4-D. Chem. Eng. J. 391, 123605.

Zhu, Y., et al., 2019. Strategies for enhancing the heterogeneous Fenton catalytic reactivity: a review. Appl. Catal. B Environ. 255, 117739. 